\title{
Multi-regional Neurodegeneration in Alzheimer's disease: Meta-analysis and data integration of transcriptomics data
}

\author{
Karbalaei, Reza ${ }^{1}$; Rezaei Tavirani, Mostafa ${ }^{1}$; Torkzaban, Bahareh ${ }^{2,3}$; Azimzadeh, Sadegh ${ }^{4}$ *
}

1. Proteomics Research Center, Faculty of Paramedical Sciences, Shahid Beheshti University of Medical Sciences, Tehran, Iran

2. National Institute of Genetic Engineering and Biotechnology, Tehran, Iran

3. Current address: Department of Neuroscience, Lewis Katz School of Medicine at Temple University, Philadelphia, PA10140, USA

4. Chemical Injuries Research Center, Baqiyatallah University of Medical Sciences, Tehran, Iran

*: Correspondence 


\section{Abstract}

Alzheimer's disease $(A D)$ is a complex neurodegenerative disease with various deleterious perturbations in regulatory pathways of various brain regions. Thus, it would be critical to understanding the role of different regions of the brain in initiation and progression of $A D$, However, owing to complex and multifactorial nature of this disease, the molecular mechanism of AD has yet to be fully elucidated. To confront with this challenge, we launched a meta-analytical study of current transcriptomics data in four different regions of the brain in AD (Entorhinal, Hippocampus, Temporal and Frontal) with systems analysis of identifying involved signaling and metabolic pathways. We found different regulatory patterns in Entorhinal and Hippocampus regions to be associated with progression of AD. We also identified shared versus unique biological pathways and critical proteins among different brain regions. ACACB, GAPDH, ACLY, and EGFR were the most important proteins in Entorhinal, Frontal, Hippocampus and Temporal regions, respectively. Moreover, eight proteins including CDK5, ATP5G1, DNM1, GNG3, AP2M1, ALDOA, GPI, and TPI1 were differentially expressed in all four brain regions, among which, CDK5 and ATP5G1 were enriched in KEGG Alzheimer's disease pathway as well.

\section{1- Introduction}

As a chronic neurodegenerative disorder, Alzheimer's disease (AD) is exhibiting deleterious effects on patients, caregivers, and families [1]. Based on Alzheimer's Disease International Federation (ADI) report at the current rate, 46.8 million people living with dementia worldwide, with numbers projected to nearly double every 20 years, increasing to 74.7 million by 2030 and 131.5 million by 2050 [2]. Also, they estimated that the Medicare/Medicaid spending in 2015 totaled US $\$ 818$ billion (about four times more than what was predicted in 2005 namely US $\$ 216$ billion) and estimates that the global cost of dementia will have reached US\$1 trillion in 2018 [2]. 

aCC-BY-NC-ND 4.0 International license.

Early $A D$ diagnosis in combination with new classes of neuroprotective or disease-modifying drug treatments may delay or prevent the neurodegenerative effects of $A D$ [3]. Attempts at symptomatic relief are only modestly effective ,and still, there isn't a proper report on some curative treatment [4], although many researchers focused on different aspects of this disease and tried to shed light on its diagnosis [5]. However, due to long preclinical and prodromal phases and the symptom-free episodes, the initiating factors of $A D$ are still unclear, and it seems likely that a sort of brain damage starts a decade or more before problems become evident [5]. So, AD continuously is a major target of both clinical and basic types of research.

It is assumed that many factors and their interactions contribute to the pathogenesis of AD. Thus, a holistic research regarding the mechanism of $A D$ is of great importance $[6,7] . A D$ is a multi-factor disease that has two forms, early onset familial Alzheimer disease (EFAD) that inherited in an autosomal dominant manner [8] and Late-onset Alzheimer's disease (LOAD) or non-familial [9] that appears as a much more complex or multifactorial disease [10]. The point is that regardless the Alzheimer's form there isn't any significant diagnostic report before the appearance of Alzheimer's hallmarks.

The AD's hallmarks associated with microscopic features including appearance of Neurofibrillary Tangles [11], Amyloid Plaques [12], Cerebral Amyloid Angiopathy [13], Granulovacuolar Degeneration and Hirano Bodies [14], Glial Responses [15], Neuronal Loss [16] and Synapse Loss [17] which lead to appearance of the macroscopic features described by Braak in 1991 [18]. Braak stages of I and II represent the situation that neurofibrillary tangles of the transentorhinal region of the brain are involved. At the stages of III and IV the limbic region (such as the Hippocampus) is also involved and finally, at the stages of $\mathrm{V}$ and $\mathrm{VI}$, an extensive neocortical involvement is detectable [18]. Altogether, abnormal deposits of proteins form amyloid plaques and tau tangles throughout the brain, leading to deficits in neurons plasticity and apoptosis and the resultant brain shrinkage over the time. With damage reaching the 

aCC-BY-NC-ND 4.0 International license.

Hippocampus, (stage III and IV), substantial memory loss would be expected has been shrunken significantly [9].

Classical reductionist research methods are incapable of coping the complex nature of multifactorial diseases such as AD in which, both individual's genetic background and environmental conditions are involved. Thus a systems level methodology with an integrative and holistic approach would be highly demanding in this area to identify critical interactions between hereditary and environmental factors. .Also, models were designed by these approaches to understanding initiation. To reach this goal, A large number of microarray datasets belonging to different brain regions of $A D$ patients are available [19-21] in public databases. Herein, we used these data to shed light on the role of important pathways in brain regions associated with $A D$. In this regard we meta-analyzed qualified microarray data belonging to four brain regions of patients with $A D$ including Entorhinal, Frontal, Hippocampus, and Temporal) and followed a network-based approach to identify brain-region-specific pathways/genes. Furthermore, we supplemented our results with current knowledge- and data-driven networks to decipher possible crosstalk between Hippocampus-Frontal in the brain regions of Alzheimer's patients.

\section{2- Materials and methods}

\section{2-1 Data collection}

In general, 110 data-series belonging to 8 regions of brain deposited in GEO and Array Express databases based on "Alzheimer" and "Homo sapiens" keywords. To decrease heterogeneity as well as increasing the consistency between expressing data-series, only Human Genome U133 Plus 2.0 Array (HG-U133_Plus_2) or Human Genome U133A ver2.0 (U133A) platforms from Affymetrix Company were selected. Finally, the data-series of four regions including Entorhinal, Frontal, Hippocampus and Temporal out of eight brain regions were selected after quality assessment. A summary of the above procedures and the applied methods is presented in figure 1. 


\section{2-2 Gene expression data analysis and meta-analysis}

To compile expression data for meta-analysis, CEL raw files were reprocessed in the following steps. First, quality of each microarray sample was assessed using the R package "array Quality Metrics" [22]. Second, normalization of raw data series was carried out using Just-RMA algorithm [23]. Third, expression data of each region of the brain was qualified for meta-analysis using MetaOmics package in $\mathrm{R}$ [24]. MetaOmics" software is a unified R package including several tools such as MetaQC and MetaDE. The MetaQC package performs principal component analysis (PCA) and standardized mean rank summary (SMR) score based on calculated six quality control (QC) measures to identify problematic studies and exclusion of heterogeneous samples [25] (Figure 2). Consequently, datasets for each brain region (Entorhinal, Frontal, Hippocampus, and Temporal) were qualified (Table 1). Afterward, a metaanalysis was performed using Fisher's combined probability test in MetaDE package for each brain region [26] (Table S1). Benjamini-Hochberg Adjustment used for adjustment of p-values [27, 28]. Also, fold change of $\geq|2|$ and false discovery rate ("FDR) $\leq 10-3$ " was used for identification of differential gene expression. In order to compare four brain regions, unique DEGs of each region (DEGs that only express in one region) was selected, sorted based on their fold change, and top 10\% of DEGs were enriched for GO Biological Process (Table S2).

\section{2-3 Pathway enrichment and integration}

The contribution of DEGs in different pathways was investigated using enrichment of DEGs in Enrichr web server [29, 30]. Enrichr performs enrichment analysis for the input genes against several data-libraries including complete data of Kyoto Encyclopedia of Genes and Genomes (KEGG) database

(Release 78.0, April 1, 2016) [14, 31]. All significant pathways ( $p$-value < 0.05) were identified for each meta-analyzed region of the brain involved in AD (Table 2). The enriched pathways were classified as "identical" assuming shared pathways among all four studied brain regions and "non-Identical" pathways, 
bioRxiv preprint doi: https://doi.org/10.1101/245571: this version posted Januarv 9. 2018. The copvriaht holder for this preprint (which was not certified by peer review) is the author/funder, who has granted bioRxiv a license to display the preprint in perpetuity. It is made available under aCC-BY-NC-ND 4.0 International license.

to address to other pathways which may be identical between two or three of them. Also, enriched pathways were categorized in three classes including signaling, metabolic, and disease (Table 2).

\section{2-4 Network reconstruction}

A network is a graph of nodes (genes/proteins) and edges (interactions) [32]. In this study, we reconstructed two networks based on knowledge- and data-driven approaches. First, a protein-protein interaction network (PPI) was constructed based on prior knowledge of signaling and metabolic pathways in different pathway databases (section 5-1). Then, a reverse-engineering approach was applied as a data-driven method (section 5-2).

\section{2-4-1- knowledge-driven network reconstruction}

The Search Tool for the Retrieval of Interacting Genes/Proteins (STRING), a database for predicted protein-protein interactions at EMBL. It is clustering the extracted results from many proteinprotein interactions databases, like Mint, BioGrid, etc. It also uses the information from KEGG pathways and Reactome to provide the best annotations for the interactions of one protein. We constructed a network by submitting DEG list to STRING database of protein-protein interaction to create Brain PPI Network in Alzheimer's disease (BPNA) (Figure 6) representing the multi-regional network in the brain of Alzheimer's patients. BPNA network was decomposed into five sub-networks to identify region-specific networks including BPNA $A_{S E E D}$ (proteins of identical pathways which is described in section-4), BPNA $A_{F R O}$ (proteins of non-identical pathways of the Frontal region), BPNA $A_{E N T}, B P N A_{H I P P}$ and $B P N A_{T E M}$ as is illustrated in figure 8 (Table S3).

\section{2-4-2- Data-driven network reconstruction}

In this step, we have tried to reverse engineer a gene regulatory network (GRN). In this research, ARACNe (Algorithm for the Reconstruction of Accurate Cellular Networks) was used to construct a Gene

Regulatory Network (GRN) for each of the brain regions [33, 34]. ARACNe network of each brain region 
bioRxiv preprint doi: https://doi.org/10.1101/245571; this version posted January 9,2018 . The copyright holder for this preprint (which was not certified by peer review) is the author/funder, who has granted bioRxiv a license to display the preprint in perpetuity. It is made available under aCC-BY-NC-ND 4.0 International license.

was constructed based on the dataset with the best score in the MetaQC analysis. Mutual information(MI)

threshold and Data Processing Inequality (DPI) tolerance set to 0.05 and $0 \%$, respectively [35].

\section{2-5 Network Analysis}

All constructed networks (PPI/GRN) were assessed for topological properties such as

Betweenness centrality (B.C), closeness centrality (C.C), the degree of the nodes and topological coefficient (Table S4 and S5) [36, 37]. Additionally, Newman's modularity (community) algorithm was applied for detection of the strength of division of the network into modules [38].

\section{2-6 Clustering and Correlation Analysis}

Correlation between brain regions was performed using expression data of DEGs (section 2) from case (patients) samples of the GSE5281 dataset (best score in MetaQC test, refer to section 2) in R software by Kendall method and cor algorithm (stats package) [39]. To define effective genes in the correlation between regions, the pairwise correlation was performed using expression data of pooled DEGs from all samples of the GSE5281 dataset. Correlated gene pairs (the nodes) were connected by edges to create a correlation network. A number of edges and nodes of pairwise correlation were extracted and depicted by circos software [40] (Figure 4-a). Investigation of pairwise correlation between brain regions was performed to identify correlated genes (Correlation coefficient: 0.8 and p-value $<0.05$ ). Pairwise correlations results hold as networks. Topological properties of all networks were analyzed and showed these networks were scale-free, so nodes with a degree above average called hubs. The average degree of nodes and frequencies of hubs in each network were calculated. A number of nodes/hubs were compared in each paired correlation network (Figure 4-b) and were compared with other pairs.

Clustering of selected genes between samples was performed to investigate related genes in brain regions based on their expression data of case samples using "dendextend" package [41] (Figure 5-b). The number of clusters was determined by "fviz dend" algorithm in this package (Figure S1). Results of 
bioRxiv preprint doi: https://doi.org/10.1101/245571; this version posted January 9, 2018. The copyright holder for this preprint (which was not certified by peer review) is the author/funder, who has granted bioRxiv a license to display the preprint in perpetuity. It is made available under aCC-BY-NC-ND 4.0 International license.

dendrogram were shown in Table S6 and the complete results supplied in supplementary files (Figure S1).

Clustered genes were enriched based on their class by Enrichr database (refer to section 3). For a better understanding of relationships between regions, clustering of brain regions was performed on data (Figure 5-a). Finally, expression of all probesets was applied to draw clustering dendrogram between regions (Figure 3).

\section{2-7 Cross-validation}

We used two methods of cross-validation including literature mining and reconstruction of gene regulatory network of ARACNe. First, differential and critically identified proteins in BPNA were used for literature mining (Table S7). Then, ARACNe network was constructed for each region of the brain. Afterward, results were compared between different methods. Nodes with a degree above average were selected as hubs. Also, Hubs were extracted and compared to intra- and inter-region correlation results. 


\section{3- Results}

Despite the clinical progression and advanced studies in the field of Alzheimer`s disease (AD), its diagnosis and curation remain unclear. Many separated meta-analytical studies suggested the possibility of sharing a common feature among different AD brain regions [42-44]. Herein, we have tried horizontal and vertical data integration approach to unify heterogeneous microarray studies for several regions of the brain in $A D$ patients and investigate their possible signaling and regulatory relationships. Also, a network approach was followed to investigate key effective genes in the initiation and progression of AD through different brain regions.

\section{3-1 Meta-analysis and Gene expression analysis result}

Among 110 transcriptomics brain studies in Alzheimer's patients with about 2000 samples in overall, four brain regions including Entorhinal, Frontal, Hippocampus, and Temporal were selected for meta-analysis following quality assessment and just in Temporal region one sample was excluded (Figure 2 and Table 2). Afterward, DEGs in each brain region were identified (FDR $\leq 10^{-3}$, fold change $>$ I2I)". Hippocampus region with 1438 genes presented the highest number of DEGs, and the Entorhinal region with 486 genes showed the lowest number of DEGs. Frontal and Temporal regions with 1131 and 998 genes ranked between Hippocampus and Entorhinal, respectively. Detailed results for meta-analysis of each brain region is provided in the supplementary file of Table S1.

By analyzing top $10 \%$ unique DEGs of each region, it was determined that each region has different functional pattern than another region. In Entorhinal region (with 307 unique DEGs), most of the top DEGs contribute in Metabolic pathways, such as amino acids, fatty acid, and carbon metabolism, but in Hippocampus (with 730 unique DEGs) oxidative phosphorylation, mitochondrial related pathways and ataxia were enriched. In Frontal region (with 407 unique DEGs) selected DEGs highlighted MAPK and RAS signaling pathways and neuropathy disease, however, in the Temporal region (with 419 unique 
bioRxiv preprint doi: https://doi.org/10.1101/245571; this version posted January 9,2018 . The copyright holder for this preprint (which was not certified by peer review) is the author/funder, who has granted bioRxiv a license to display the preprint in perpetuity. It is made available under aCC-BY-NC-ND 4.0 International license.

DEGs) adherens junction was important pathway along with muscular dystrophy was the pathological term

(Table S2).

\section{3-2 Comparison of expression data among different brain regions}

In the first step of correlation analysis, all genes in all samples of brain regions were clustered

(Figure 3). Generally speaking, clustering of brain samples showed that Entorhinal has a negative correlation with other brain regions, while there are some positive and negative correlations between the samples from Frontal, Temporal and Hippocampus regions. To identify effective genes, pairwise correlation analysis was performed using selected genes in all samples (Figure 4-a). The resulting six pairwise correlation networks were constructed to identify shared edges between regions (Figure 4-a). Percent of similarity between different brain regions (number of nodes from one region/number of all nodes of that region) is illustrated in figure 4-a. This comparison showed that in each pairwise correlation, a region with a high average degree in nodes has a low frequency in hubs and may have a regulatory role over other regions. Figure 4-b is a summarized graph of the figure 4-a in which arrows show the pairwise correlation. Also, numbers indicate the nodes of each region that contribute in the pairwise correlation. Results showed that Entorhinal region has less number of hubs than other regions in each comparison.

The samples from different brain regions were classified based on; a- all expression data and b-

DEGs. All four brain regions are clearly clustered when all genes are used for clustering (Figure. 5a). However, clustering of brain regions based selected DEGs showed different results (Figure 5b). Interestingly, almost all Entorhinal samples are clustered in one distinct group, and other samples of three other regions are co-clustered. Therefore, gene expression profile in Entorhinal shows a different pattern in comparison with other brain regions.

Additionally, DEGs were clustered in two distinct groups of up-regulated and down-regulated genes (Figure 6 and Table S6). Each cluster was used for gene enrichment analysis (Table S6). 
bioRxiv preprint doi: https://doi.org/10.1101/245571; this version posted January 9,2018 . The copyright holder for this preprint (which was not certified by peer review) is the author/funder, who has granted bioRxiv a license to display the preprint in perpetuity. It is made available under aCC-BY-NC-ND 4.0 International license.

Neurodegenerative disease pathways (including AD, Huntington, and Parkinson) and oxidative phosphorylation pathways were enriched for the up-regulated cluster ,but cell cycle and proteasome were enriched for the down-regulated cluster (Adjusted p-value $<0.05$ ).

\section{3-3 Pathway enrichment and integration}

After gene enrichment in Enrichr, Totally, about 97 KEGG's pathways were identified for Entorhinal, Frontal, Hippocampus, and Temporal with eight overlapping pathways among these pathways (Table 2).

\section{3-4 PPI network reconstruction and analysis}

3-4-1 knowledge-driven network analysis:

Proteins of enriched pathways were merged and used to reconstruct BPNA PPI network in STRING database. BPNA was a scale-free network of 727 nodes and 8974 edges. The network comprised of eight modules. About $10 \%$ of BPNA nodes (75 nodes) belonged to KEGG Alzheimer's disease pathway. The degree of about $78 \%$ of these nodes was above average. $66 \%$ of KEGG Alzheimer's disease pathway was clustered in one module. Eight proteins were dysfunctional in all four regions including DNM1, GNG3, AP2M1, CDK5, ATP5G1, ALDOA, GPI, and TPI1. NDUFB1, NDUFA2, NDUFB4 and NDUFB11 and showed different behavior compared to other hub proteins in their closeness index. Interestingly, proteins of KEGG Alzheimer's disease pathway tend to have a high degree.

To determine the effective pathways in each brain region and related to Alzheimer progression, BPNA network was decomposed into two sub-network groups based on eight identical pathways and nonidentical pathways (enrichment results) of the brain region. Proteins of eight identical pathways were used

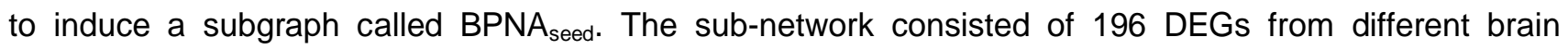
regions (figure 7). Afterward, proteins from non-identical enriched pathways were used to induce four 
brain-region-specific sub-graphs including BPNA $\mathrm{FRO}_{\text {(208 }}$ proteins), BPNA $\mathrm{ENT}_{\text {( }}$ (75 proteins), BPNA $\mathrm{HIPP}_{\text {( }} 407$

proteins) and BPNA

The frequency of protein numbers in identical pathways for different brain regions in figure 8 indicate that the Hippocampus region includes the most proteins in each identical pathway, most of the non-identical pathways belonged to Hippocampus and Entorhinal includes the less number of pathways (Table 2).

All decomposed networks constructed from BPNA are represented in figure 9 (proteins of all selected pathways). In BPNA $A_{S E E D}$ network (Figure 9-a), disease pathways (24\%), signaling pathways (16\%) and metabolic pathways (12\%) have the most number of specific proteins. Interestingly, 21 of 25 high degree proteins, belonged to KEGG Alzheimer's disease pathway. UQCRC1, NDUFB1, NDUFB4, NDUFB11, NDUFA2, NDUFA5 and GAPDH were hub proteins of this brain region in AD patients. Interestingly, in this network GAPDH was special protein belonging to all three mentioned classes of pathways, also is a KEGG Alzheimer's disease pathway protein and were in top ten lists of high degree proteins, first in high B.C and C.C and $9^{\text {th }}$ in low topological coefficient.

Figure 9 b-e is representing specific sub-graphs. In Entorhinal region (BPNA $A_{E N T}$ ), ACACB protein (expressed in both metabolic and signaling pathways) has the highest degree (Figure 9-c). In this subnetwork, NDUFB4, NDUFS7, NDUFB7, and ATP5D, were proteins that have a degree above average (Hub) but very low B.C and C.C.ADCY9 (the enzyme that catalyzes the formation of the cyclic AMP from ATP) was the only protein that contributed in all three classes of pathways.

In BPNA $_{F R O}$ GAPDH (a protein of KEGG Alzheimer's disease pathway) had the highest degree,

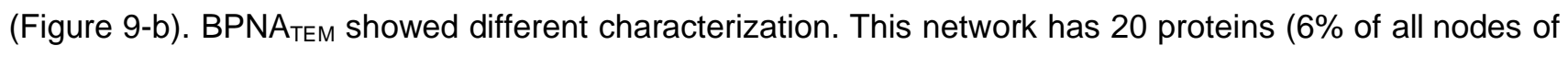
this network) that contributed in all signaling, metabolic and disease pathways and interestingly almost all of them modularized in oxidative phosphorylation pathway (based on KEGG Mapper analysis). These proteins include UQCRFS1, UQCR10, UQCRQ, UQCRC2, COX5A, UQCRC1, COX8A, ATP6V1H, 
bioRxiv preprint doi: https://doi.org/10.1101/245571; this version posted January 9, 2018. The copyright holder for this preprint (which was not certified by peer review) is the author/funder, who has granted bioRxiv a license to display the preprint in perpetuity. It is made available under aCC-BY-NC-ND 4.0 International license.

ATP6V1B2, ATP6V0A1, ATP6V0C, ATP6V1E1, ATP6V0D1, ATP6V0E2, ATP6V0B, ATP6V0E1, ATP6V1G2, ATP6AP1, ATP6V1D, and PLCG1. First seven proteins also contribute to KEGG Alzheimer's

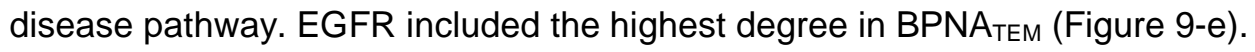

Finally, BPNA $A_{\text {HIPP }}$ contained 391 nodes and was the largest sub-network. ACLY had the highest degree in BPNA ${ }_{\text {HIPP }}$ network (Figure 9-d).

\section{3-4-2 Data-driven network reconstruction: ARACNe}

Based on the MetaQC analysis, GSE5281 data series were selected for ARACNe analysis in all four brain regions. The resulted ARACNe networks included 5380 nodes and 28795 edges in Entorhinal, 4993 nodes and 12835 edges in Frontal, 4732 nodes and 29044 edges in Hippocampus and 5337 nodes and 42547 edges in the Temporal region. To have a glance at resulted networks, top 10 genes in degree and their first neighbors were extracted, and new networks were enriched, separately. Pathways with adjusted $p$-value $<0.05$ were selected and shown in Table 3 . Entorhinal regions showed the minimum and different pathways than other regions, indeed just two pathways of Entorhinal shared with another region (Temporal) and highlighted in Table 3. But three remained regions have four shared pathways including Oxidative phosphorylation, Synaptic vesicle cycle, epithelial cell signaling in Helicobacter pylori infection and finally Vibrio cholerae infection.

\section{3-5 Cross-validation}

All differentially expressed genes during this meta-analysis are available in Table S7. We have reported 100 Up and 486 down-regulated genes in Alzheimer disease in all brain regions completely that

more than $75 \%$ of our reported in each group were validated. Summary of Cross-validation statistic is shown in Table 4. 


\section{4- Discussion:}

Relating global expression pattern of multiple genes in $A D$ to the different regions of the brain and deciphering $A D$ progression in these regions is a serious part of the research because $A D$ is one of the most common neurodegenerative disorders. Some related studies on brain regions of Alzheimer patients were accomplished previously. Ray et al. by analyzing microarray data of brain regions showed that middle temporal gyrus is a good choice for detecting early AD pathogenesis [43]. Wang et al. extract sample from 19 cortical regions of 125 individuals and after defining DEGs and ranking brain region based on relevance to $\mathrm{AD}$, construct co-expression networks for each brain region. Their analyses identified temporal lobe gyri as earliest gene expression abnormalities region [45].

Our meta-analysis results showed that Entorhinal region has the minimum number of DEGs with respect to other regions. Also in some analysis results, Entorhinal showed consistently unique behavior compared to other regions: A) In correlation analysis: displayed negative correlation with other brain regions (Figure 3), B) In clustering of all DEGs (Figure 5-b), Entorhinal samples were classified in a separate from samples of other regions C) In Gene set enrichment analysis, Entorhinal region contained non-identical pathways with metabolic pathways owning the highest number of pathways, while in other regions, the highest number of pathways were related to signaling pathways, Entorhinal had also few hubs with high average degree in each pairwise correlation (Table 2) and finally D) In pathway enrichment analysis on selected genes in GRN analysis, list of Entorhinal pathways were different compared to other regions (Table 3). Interestingly, there are several integrative observations indicating the beginning of $A D$ from entorhinal [46-49]. Mapping of histology and imaging-based data (MRI and PET) in different studies have revealed the critical and initial function of the entorhinal region in AD pathogenesis. We have also 
observed different expression pattern for entorhinal (more hubs and inverse pairwise correlation) in comparison to other studied regions.

The results of meta-analysis also indicated the highest number of DEGs in Hippocampus. Pairwise and correlation gene expression analysis between regions of brain w showed that Entorhinal region has different manner with respect to other regions and control another part of the brain (see above). Reviewing clinical case studies on the $A D$ patient whose disease progression has been monitored using brain imaging techniques demonstrated that brain atrophy initiated from the limbic lobe (Entorhinal and Hippocampus regions) to Temporal and will reach to Frontal region [50]. Moreover, the Hippocampus and Entorhinal atrophy is a clinically relevant AD diagnostic measure in patients [51]. Interestingly, our results impress on the importance of these two regions. Enrichment results for top $10 \%$ differential genes in each brain region indicate their different functioning in which hippocampus, frontal and temporal regions were enriched in pathological terms including ataxia, neuropathy and muscular dystrophy, respectively [52-54].

A clear crosstalk was observed between various brain regions in AD patients so related pathways some of which are shared among regions- were functioning simultaneously. Also, two distinct classes of pathways were over- (neurodegenerative diseases and related pathways) and under- (cell cycle and proteasome) represented. Because of limitation in data sources, results of this research were not ideal, and by sampling from all brain regions of $A D$ patients, can perform completely. Altogether, application meta-analysis in connects to complete sampling resulted in identifying beginning and progression factors of $A D$.

We observed that GAPDH had the highest node degree protein in Hippocampus and frontal regions, in addition, this protein was connected to proteins in all brain regions. GAPDH isoforms have been found in the brains of $A D$ patients [55]. The eight proteins which were dysfunctional in all four regions were directly involved in the pathogenesis of AD. ALDOA, GPI, and TPI1 are involved in inflammatory pathways in AD via induction of inflammation [56], activation of $\beta$-secretase [57], and nitrotyrosination of 
bioRxiv preprint doi: https://doi.org/10.1101/245571; this version posted January 9,2018 . The copyright holder for this preprint (which was not certified by peer review) is the author/funder, who has granted bioRxiv a license to display the preprint in perpetuity. It is made available under aCC-BY-NC-ND 4.0 International license.

proteins, respectively. AP2M1 and DNM1 contribute to the degradation of $\beta$-amyloids and abnormal mitochondrial dynamics which lead to impaired synaptic degeneration and signaling, respectively [58-60]. GNG3 another member of this list encodes gamma subunit of Guanine nucleotide-binding protein $\mathrm{G}(\mathrm{I}) / \mathrm{G}(\mathrm{S}) / \mathrm{G}(\mathrm{O})$ which is required for GTPase and is its dysregulation is involved in the initiation of $A D$ [61].

Cdk5 and ATP5G1 are involved in mitochondrial dysfunction in AD. CDK5 is one of the most studied and critical proteins in AD pathogenesis involved in neuronal migration, differentiation, synaptic functioning and memory consolation. Its hyperactivity and deregulation cause many of pathological outcomes in AD [62]. Also, decreased activity of ATP5G1 (ATP synthase) along with its partners in respiratory chain is reported in $\mathrm{AD}$ [63].

In all depicted networks, proteins involved in AD pathogenesis tend to contribute in one module, showing high relation and communication (such as protein-protein interactions) between them. Also, most of the AD genes were hubs in mentioned networks that can be related their active roles in samples. Additionally, a wide range of effective proteins was identified which are belonging to glycolysis (GADPH), mitochondrial electron chain (ATP5C1) or folding of proteins (HSPA8), the main effective factors in AD progression. Combining proper microarray data in this meta-analysis, and their comparison concluded to a noteworthy clustering.

\section{5- Conclusion}

In this study, we investigated the pattern of damage flow through multiple regions of the brain in $A D$ using meta-analysis techniques. Moreover, the result of this study is consistent with former findings on protein expression pattern in the network of neurodegenerative diseases with special focus on AD. By linking the sequence of disease progression through multiple brain regions with DEGs observed in each brain area, the key role of underlying genes associated with initiation and progression of the disease. 
bioRxiv preprint doi: https://doi.org/10.1101/245571; this version posted January 9, 2018. The copyright holder for this preprint (which was not certified by peer review) is the author/funder, who has granted bioRxiv a license to display the preprint in perpetuity. It is made available under aCC-BY-NC-ND 4.0 International license.

Besides, we showed meta-analysis techniques to be reliable in studying effective factors in disease

progressing by creating an overall scope of operating disease factors. Altogether, we have identified that entorhinal shows different expression profiling than other three studies regions. 


\section{6- References:}

.1 Reitz C, Brayne C, Mayeux R. Epidemiology of Alzheimer disease. Nature Reviews Neurology. 2011;7(3):137-

.2 Prince MJ. World Alzheimer Report 2015: The Global Impact of Dementia: an Analysis of Prevalence, Incidence, Cost and Trends2015.

.3 Ho L, Fivecoat H, Wang J, Pasinetti GM. Alzheimer's disease biomarker discovery in symptomatic and asymptomatic patients: experimental approaches and future clinical applications. Experimental gerontology. 2010;45(1):15-22.

.4 Mangialasche F, Solomon A, Winblad B ,Mecocci P, Kivipelto M. Alzheimer's disease: clinical trials and drug development. The Lancet Neurology. 2010;9(7):702-16.

.5 Brier MR, Thomas JB, Ances BM. Network dysfunction in Alzheimer's disease: refining the disconnection hypothesis. Brain connectivity. 2014;4(5):299-311.

.6 Ikonen M, Liu B, Hashimoto Y, Ma L, Lee K-W, Niikura T, et al. Interaction between the Alzheimer's survival peptide humanin and insulin-like growth factor-binding protein 3 regulates cell survival and apoptosis. Proceedings of the National Academy of Sciences. 2003;100(22):13042-7.

.7 Jiang W, Zhang Y, Meng F, Lian B, Chen X, Yu X, et al. Identification of active transcription factor and miRNA regulatory pathways in Alzheimer's disease. Bioinformatics. 2013;29(20):2596-602.

$.8 \quad$ Bird TD. Early-onset familial Alzheimer disease. 2012.

.9 Hardy J. A hundred years of Alzheimer's disease research. Neuron. 2006;52(1):3-13.

.10 Rhinn H, Fujita R, Qiang L, Cheng R, Lee JH, Abeliovich A. Integrative genomics identifies APOE $\varepsilon 4$ effectors in Alzheimer's disease. Nature. 2013;500(7460):45-50.

.11 KIDD M. Alzheimer's disease-an electron microscopical study. Brain. 1964;87(2):307-20.

.12 Jack CR, Lowe VJ, Weigand SD, Wiste HJ, Senjem ML, Knopman DS, et al. Serial PIB and MRI in normal, mild cognitive impairment and Alzheimer's disease: implications for sequence of pathological events in Alzheimer's disease. Brain. 2009:awp062.

.13 Knudsen KA, Rosand J, Karluk D, Greenberg SM. Clinical diagnosis of cerebral amyloid angiopathy: validation of the Boston criteria. Neurology. 2001;56(4):537-9.

.14 Ashburner M, Ball CA, Blake JA, Botstein D, Butler H, Cherry JM, et al. Gene Ontology: tool for the unification of biology. Nature genetics. 2000;25(1):25-9.

.15 Serrano-Pozo A, Mielke ML, Gómez-Isla T, Betensky RA, Growdon JH, Frosch MP, et al. Reactive glia not only associates with plaques but also parallels tangles in Alzheimer's disease. The American journal of pathology. 2011;179(3):1373-84.

.16 Woodhouse A, Vickers JC, Dickson TC. Cytoplasmic cytochrome c immunolabelling in dystrophic neurites in Alzheimer's disease. Acta neuropathologica. 2006;112(4):429-37.

.17 Ingelsson M, Fukumoto $\mathrm{H}$, Newell K, Growdon J, Hedley-Whyte $\mathrm{E}$, Frosch $\mathrm{M}$, et al. Early $\mathrm{A} \beta$ accumulation and progressive synaptic loss, gliosis, and tangle formation in AD brain. Neurology. 2004;62(6):925-31.

.18 Braak H, Braak E. Neuropathological stageing of Alzheimer-related changes. Acta neuropathologica. 1991;82(4):239-59.

.19 Kong W, Mou X, Liu Q, Chen Z, Vanderburg CR, Rogers JT, et al .Independent component analysis of Alzheimer's DNA microarray gene expression data. Molecular neurodegeneration. 2009;4(1):1.

.20 Miller JA, Horvath S, Geschwind DH. Divergence of human and mouse brain transcriptome highlights Alzheimer disease pathways .Proceedings of the National Academy of Sciences. 2010;107(28):12698-703.

.21 Blalock EM, Geddes JW, Chen KC, Porter NM, Markesbery WR, Landfield PW. Incipient Alzheimer's disease: microarray correlation analyses reveal major transcriptional and tumor suppressor responses. Proceedings of the National Academy of Sciences. 2004;101(7):2173-8.

.22 Kauffmann A, Gentleman R, Huber W. arrayQualityMetrics-a bioconductor package for quality assessment of microarray data. Bioinformatics. 2009;25(3):415-6. Lazaridis EN, Sinibaldi D, Bloom G, Mane S, Jove R. A simple method to improve probe set estimates from oligonucleotide arrays. Mathematical biosciences. 2002;176(1):53-8.

.24 Wang X, Kang DD, Shen K, Song C, Lu S, Chang L-C, et al. An R package suite for microarray meta-analysis in quality control, differentially expressed gene analysis and pathway enrichment detection. Bioinformatics. 2012;28(19):2534-6. 
bioRxiv preprint doi: https://doi.org/10.1101/245571; this version posted January 9, 2018. The copyright holder for this preprint (which was not certified by peer review) is the author/funder, who has granted bioRxiv a license to display the preprint in perpetuity. It is made available under aCC-BY-NC-ND 4.0 International license.

.25 Kang DD, Sibille E, Kaminski N, Tseng GC. MetaQC: objective quality control and inclusion/exclusion criteria for genomic meta-analysis. Nucleic acids research. 2012;40(2):e15-e.

.26 Derkach A, Lawless JF, Sun L. Robust and powerful tests for rare variants using Fisher's method to combine evidence of association from two or more complementary tests. Genetic epidemiology. 2013;37(1):110-21.

Benjamini Y, Yekutieli D. The control of the false discovery rate in multiple testing under dependency. Annals of statistics. 2001:1165-88.

.28 Benjamini Y, Yekutieli D. Quantitative trait loci analysis using the false discovery rate. Genetics. 2005;171(2):783-90.

.29 Chen EY, Tan CM, Kou Y, Duan Q, Wang Z, Meirelles GV, et al. Enrichr: interactive and collaborative HTML5 gene list enrichment analysis tool. BMC bioinformatics. 2013;14(1):1.

.30 Kuleshov MV, Jones MR, Rouillard AD, Fernandez NF, Duan Q, Wang Z, et al. Enrichr: a comprehensive gene set enrichment analysis web server 2016 update. Nucleic acids research. 2016:gkw377.

.31 Kanehisa M, Goto S. KEGG: kyoto encyclopedia of genes and genomes. Nucleic acids research. 2000;28(1):27-

30.

.32 De Las Rivas J, Fontanillo C. Protein-protein interactions essentials: key concepts to building and analyzing interactome networks. PLoS Comput Biol. 2010;6(6):e1000807.

.33 Margolin AA, Nemenman I, Basso K, Wiggins C, Stolovitzky G, Favera RD, et al. ARACNE: an algorithm for the reconstruction of gene regulatory networks in a mammalian cellular context. BMC bioinformatics. 2006;7(Suppl

1):S7.

.34 Basso K, Saito M, Sumazin P, Margolin AA, Wang K, Lim W-K, et al. Integrated biochemical and computational approach identifies BCL6 direct target genes controlling multiple pathways in normal germinal center B cells. Blood. 2010;115(5):975-84.

.35 Yepes S, Torres MM, López-Kleine L. Regulatory network reconstruction reveals genes with prognostic value for chronic lymphocytic leukemia. BMC genomics. 2015;16(1):1.

.36 Hsu CW, Juan HF, Huang HC. Characterization of microRNA-regulated protein-protein interaction network. Proteomics. 2008;8(10):1975-9.

.37 Zhang S, Jin G, Zhang XS, Chen L. Discovering functions and revealing mechanisms at molecular level from biological networks. Proteomics. 2007;7(16):2856-69.

.38 McSweeney PJ. Gephi Network Statistics. Presentado en Google Summer of Code Recuperado a partir de http://gephi org/google-soc/gephi-netalgo pdf. 2009.

.39 Becker RA, Chambers JM, Wilks AR. The new S language. Pacific Grove, Ca: Wadsworth \& Brooks, 1988. 1988;1.

.40 Krzywinski M, Schein J, Birol I, Connors J, Gascoyne R, Horsman D, et al. Circos: an information aesthetic for comparative genomics. Genome research. 2009;19(9):1639-45.

.41 Galili T. dendextend: an R package for visualizing, adjusting, and comparing trees of hierarchical clustering. Bioinformatics. 2015:btv428.

.42 Lambert J-C, Ibrahim-Verbaas CA, Harold D, Naj AC, Sims R, Bellenguez C, et al. Meta-analysis of 74,046 individuals identifies 11 new susceptibility loci for Alzheimer's disease. Nature genetics. 2013;45(12):1452-8. Ray M, Zhang W. Analysis of Alzheimer's disease severity across brain regions by topological analysis of gene co-expression networks. BMC systems biology. 2010;4(1):1. .44 Jacobs HI, Radua J, Lückmann HC, Sack AT. Meta-analysis of functional network alterations in Alzheimer's disease: toward a network biomarker. Neuroscience \& Biobehavioral Reviews. 2013;37(5):753-65.

.45 Wang M, Roussos P, McKenzie A, Zhou X, Kajiwara Y, Brennand KJ, et al. Integrative network analysis of nineteen brain regions identifies molecular signatures and networks underlying selective regional vulnerability to Alzheimer's disease. Genome medicine. 2016;8(1):104.

.46 Gómez-Isla T, Price JL, McKeel Jr DW, Morris JC, Growdon JH, Hyman BT. Profound loss of layer II entorhinal cortex neurons occurs in very mild Alzheimer's disease. Journal of Neuroscience. 1996;16(14.500-4491:( .47 Braak H, Del Tredici K. Alzheimer's disease: pathogenesis and prevention. Alzheimer's \& Dementia. 2012;8(3):227-33.

.48 Whitwell JL, Przybelski SA, Weigand SD, Knopman DS, Boeve BF, Petersen RC, et al. 3D maps from multiple MRI illustrate changing atrophy patterns as subjects progress from mild cognitive impairment to Alzheimer's disease. Brain. 2007;130(7):1777-86.

Moreno H, Wu WE, Lee T, Brickman A, Mayeux R, Brown TR, et al. Imaging the A $\beta$-related neurotoxicity of Alzheimer disease .Archives of neurology. 2007;64(10):1467-77. 
.50 Risacher SL, Shen L, West JD, Kim S, McDonald BC, Beckett LA, et al. Longitudinal MRI atrophy biomarkers: relationship to conversion in the ADNI cohort. Neurobiology of aging. 2010;31(8):1401-18.

.51 Devanand D, Pradhaban G, Liu X, Khandji A, De Santi S, Segal S, et al. Hippocampal and entorhinal atrophy in mild cognitive impairment prediction of Alzheimer disease. Neurology. 2007;68(11):828-36.

.52 Caillet-Boudin M-L, Fernandez-Gomez F-J, Tran H, Dhaenens C-M, Buee L, Sergeant N. Brain pathology in myotonic dystrophy: when tauopathy meets spliceopathy and RNAopathy. Frontiers in molecular neuroscience. 2013;6.

.53 Jolivalt CG, Calcutt NA, Masliah E. Similar pattern of peripheral neuropathy in mouse models of type 1 diabetes and Alzheimer's disease. Neuroscience. 2012;202:405-12.

.54 Galvin JE, Palamand D, Strider J, Milone M, Pestronk A. The muscle protein dysferlin accumulates in the Alzheimer brain. Acta neuropathologica. 2006;112(6):665.

.55 Butterfield DA, Hardas SS, Lange MLB. Oxidatively modified glyceraldehyde-3-phosphate dehydrogenase (GAPDH) and Alzheimer's disease: many pathways to neurodegeneration. Journal of Alzheimer's Disease. 2010;20(2):369-93.

.56 Mor F, Izak M, Cohen IR. Identification of aldolase as a target antigen in Alzheimer's disease. The Journal of Immunology. 2005;175(5):3439-45.

.57 Sambamurti K, Sevlever D, Koothan T, Refolo LM, Pinnix I, Gandhi S, et al. Glycosylphosphatidylinositolanchored proteins play an important role in the biogenesis of the Alzheimer's amyloid $\beta$-protein. Journal of Biological Chemistry. 1999;274(38):26810-4.

.58 Tian Y, Chang JC, Fan EY, Flajolet M, Greengard P. Adaptor complex AP2/PICALM, through interaction with LC3, targets Alzheimer's APP-CTF for terminal degradation via autophagy. Proceedings of the National Academy of Sciences. 2013;110(42):17071-6.

.59 Henstridge CM, Pickett E, Spires-Jones TL. Synaptic pathology: A shared mechanism in neurological disease. Ageing research reviews. 2016;28:72-84.

.60 Kandimalla R, Reddy PH. Multiple faces of dynamin-related protein 1 and its role in Alzheimer's disease pathogenesis. Biochimica et Biophysica Acta (BBA)-Molecular Basis of Disease. 2016;1862(4):814-28.

Sfakianos MK, Eisman A, Gourley SL, Bradley WD, Scheetz AJ, Settleman J, et al. Inhibition of Rho via Arg and p190RhoGAP in the postnatal mouse hippocampus regulates dendritic spine maturation, synapse and dendrite stability, and behavior. Journal of Neuroscience. 2007;27(41):10982-92.

.62 Liu S-L, Wang C, Jiang T, Tan L, Xing A, Yu J-T. The role of Cdk5 in Alzheimer's Disease. Molecular neurobiology. 2016;53(7):4328-42.

Bonilla E, Tanji K, Hirano M, Vu TH, DiMauro S, Schon EA. Mitochondrial involvement in Alzheimer's disease. Biochimica et Biophysica Acta (BBA)-Bioenergetics. 1999;1410(2):171-82.

\section{Legends:}

Figure 1- The Summary of the overall procedure and applied methods in this article. After selection and qualification proper Alzheimer datasets (step 1 and 2), MetaDE was performed on selected datasets (step 3) and DEGs were used for knowledge-driven analysis. First, pathways enrichment using KEGG was accomplished (step 4), then by combining all proteins of selected pathways (P-value < 0.05), BPNA network was constructed (step 5). By decomposing BPNA, five networks were reconstructed (step6). On the other side, on the best dataset in each region, GRN construction (ARACNe analysis) was performed (step 7), and pairwise correlation test was performed on all selected proteins from step 3 between regions (step 8). Results from step 6 compared with step 7 (step 9). Also, expression Condition of all proteins of BPNA (Up-regulated, Down-regulated or others) were validated in literature mining and compare with results of the meta-analysis were compared (step10). For more details, see materials and methods. 
bioRxiv preprint doi: https://doi.org/10.1101/245571; this version posted January 9, 2018. The copyright holder for this preprint (which was not certified by peer review) is the author/funder, who has granted bioRxiv a license to display the preprint in perpetuity. It is made available under aCC-BY-NC-ND 4.0 International license.

Figure 2- PCA biplots of meta-analysis. Studies placed opposite to quality axes are excluded. In the Temporal region, study GSE29652 was identified as an outlier and removed from the list (a)Temporal, b) Entorhinal, c) Hippocampus, and d)Frontal.

Figure 3- Correlation between brain regions. Entorhinal samples show a negative correlation with other regions of the brain in $A D$ and were clustered in a distinct group.

Figure 4- Pairwise correlation between brain regions. a) Schematic diagram based on a percentage of edges in Hippocampus- Frontal and Entorhinal-Temporal regions, respectively. b) Pairwise correlations showed by two arrows between brain regions. At the beginning of each arrow, a number of nodes in the adjacent region and its hubs nodes (within parenthesis) are illustrated. A Total number of edges are shown between paired arrows.

Figure 5- Dendrogram and heatmap of brain regions. a) clustering of brain regions based on all probeset expression data. Samples were clustered properly except for three of them including F8, F11, and E2. b) clustering of DEGs based on their expression showed that samples from Entorhinal region are classified in a distinct group. However, samples of other regions are classified into two groups and three subgroups except for F8, F11, and E2. Abbreviations are: $\mathrm{H}=$ Hippocampus, $\mathrm{E}=$ Entorhinal, $\mathrm{F}=$ Frontal and $\mathrm{T}=$ Temporal.

Figure 6- Heatmap of clustered DEGs in two distinct groups of up-regulated and down-regulated genes

Figure 7- BPNA network contains 727 nodes. Most of the nodes belong to the hippocampus and Frontal regions. Eight proteins that are identical between all brain regions are shown in purple. GAPDH has the highest degree in the network.

Figure 8- Comparison of genes in identical pathways in each brain region. a) Identical pathways contain three signaling, two metabolic and three pathological pathways. B) Comparison of frequencies of genes in BPNA sub-networks, based on their pathway class.

Figure 9- Decomposition of BPNA network into several subnetworks. All common genes between four different brains regions are colored in gray. Unique genes are colored based on the category of biological pathways (according to Table 2). The differences in gene expression based on metaomics analysis have been illustrated with different shapes $(\boldsymbol{\Lambda}, \boldsymbol{a}$ and $\mathbf{a}$ for each of upregulated, downregulated and notdifferential genes, respectively. (a) BPNA $A_{S E E D}$ b) BPNA $A_{E N T}$ c) BPNA $A_{F R O}$ d) BPNA $A_{\text {HIPP }}$ e) BPNA $A_{\text {TEM }}$ )

Table 1- Selected datasets for Entorhinal, Frontal, Hippocampus and Temporal regions.

Table 2 list of all pathways and their appearance in brain regions. Classification performed based on a function of pathways. Identical pathways were highlighted by two-star. 
bioRxiv preprint doi: https://doi.org/101101/245571; this version posted January 9, 2018. The copyright holder for this preprint (which was not certified by peer review) is the author/funder, who has granted bioRxiv a license to display the preprint in perpetuity. It is made available under aCC-BY-NC-ND 4.0 International license.

Table 3- Comparison between selected pathways that are resulted from the enrichment of top 10 genes in degree and their neighbors of GRN networks.

Table 4-Summary of Cross-validation statistics. Numbers of up or down-regulated genes per brain region and percent of their validity in literature were shown. 


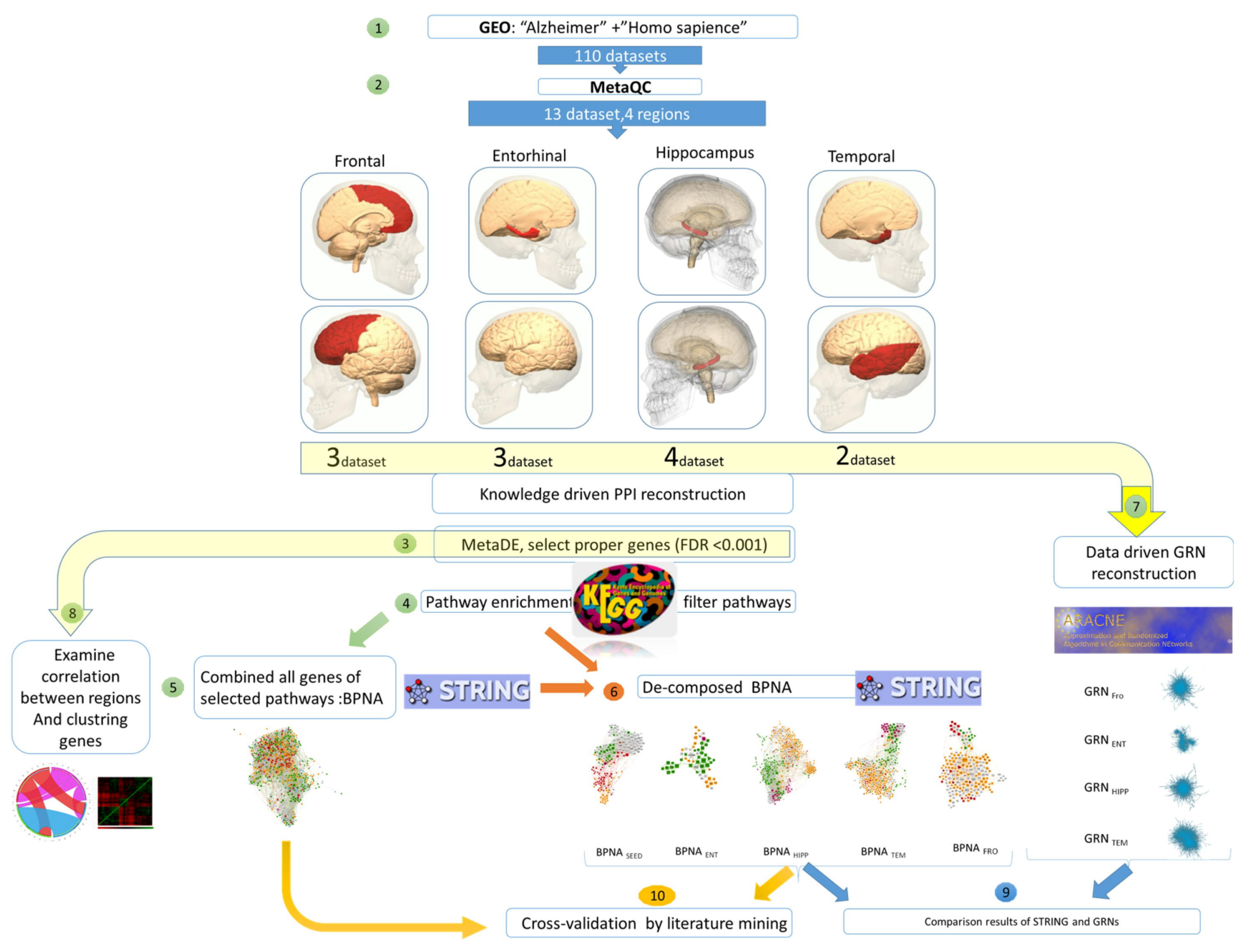


a) Temporal

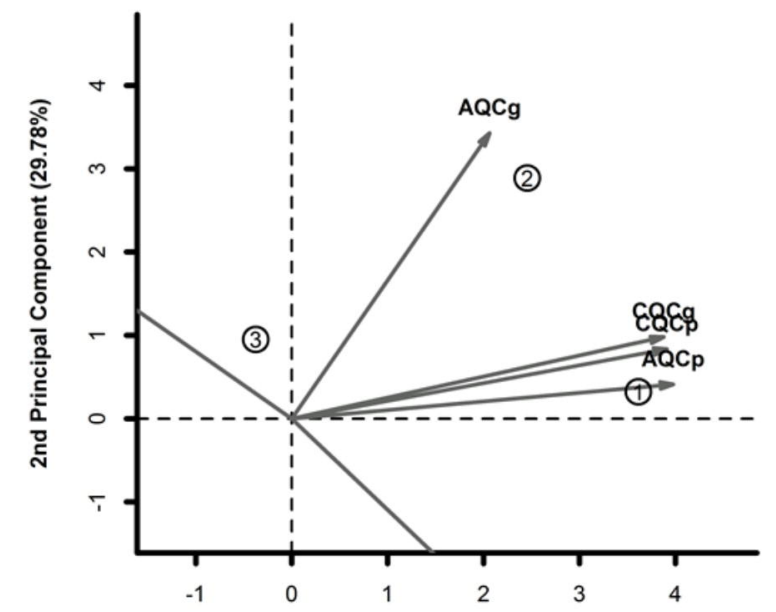

c) Hippocampus

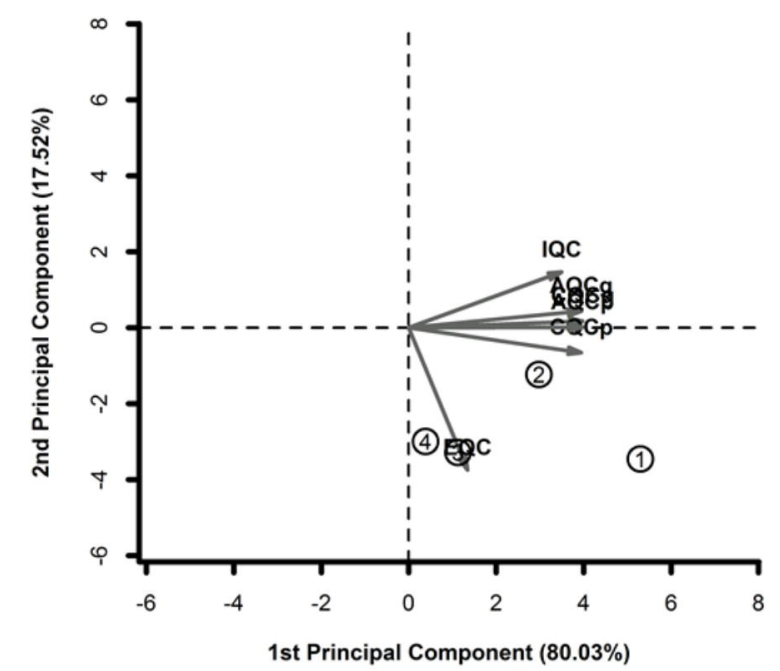

b) Entorhinal

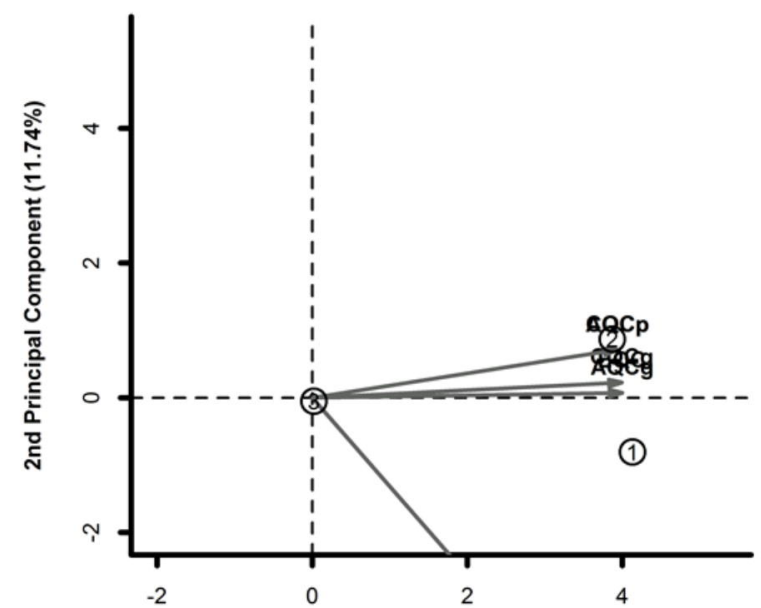

d) Frontal

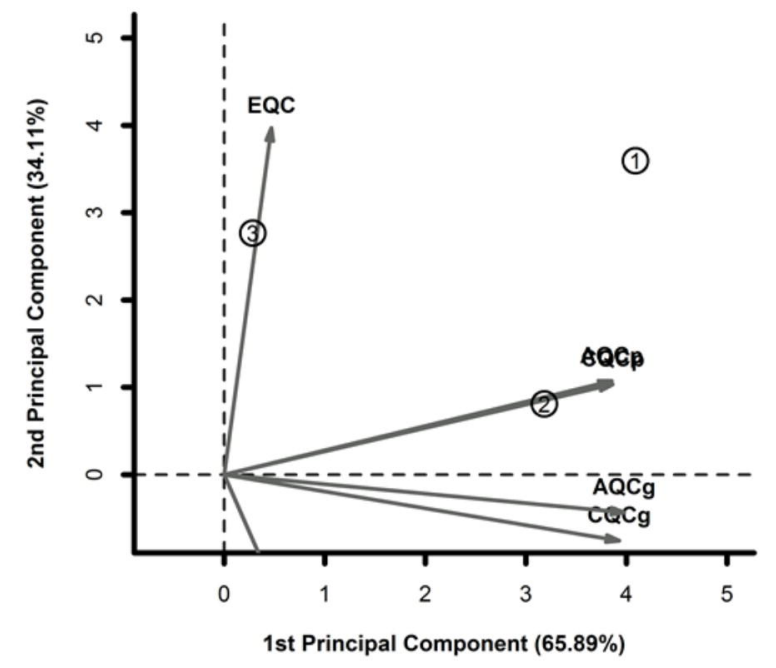




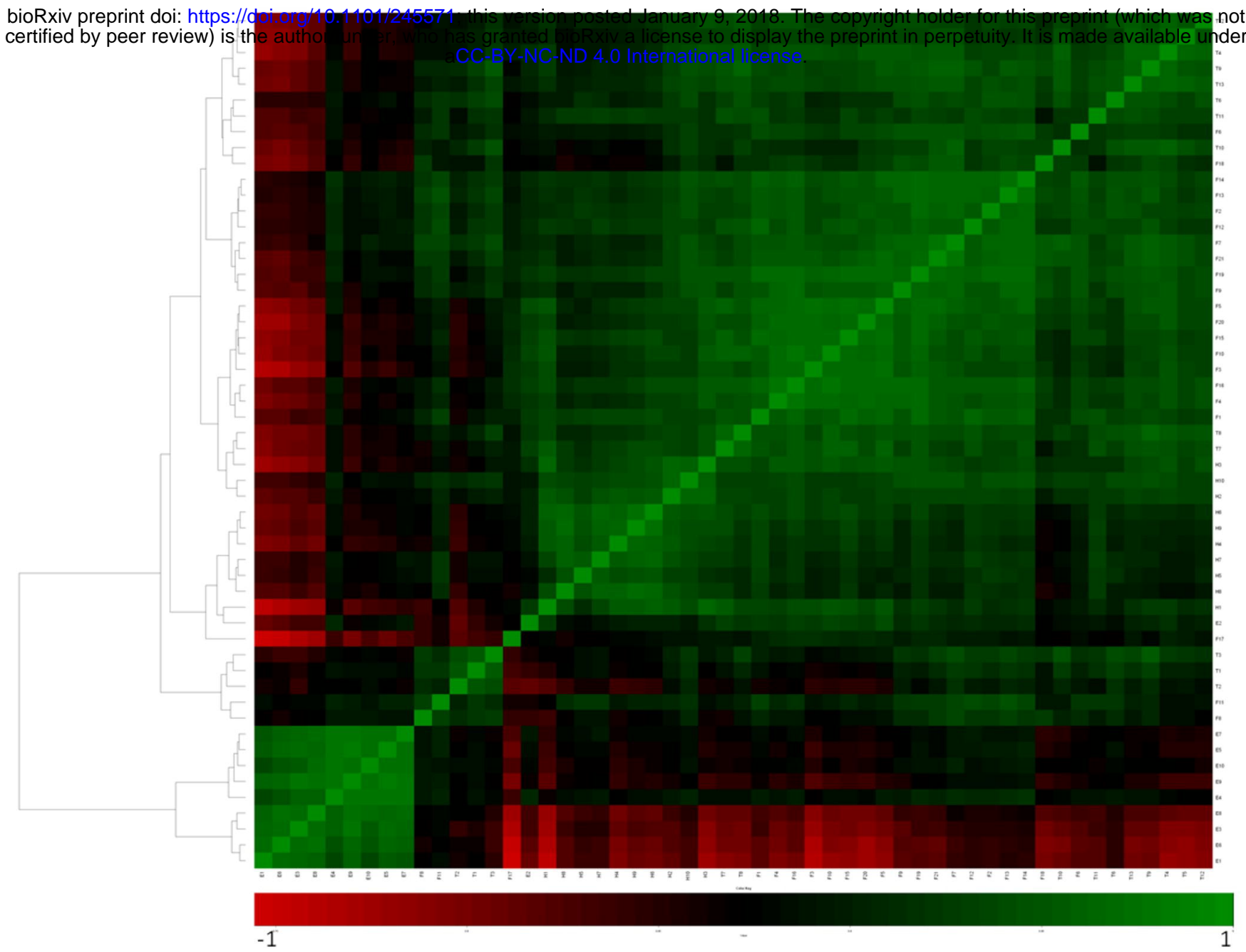




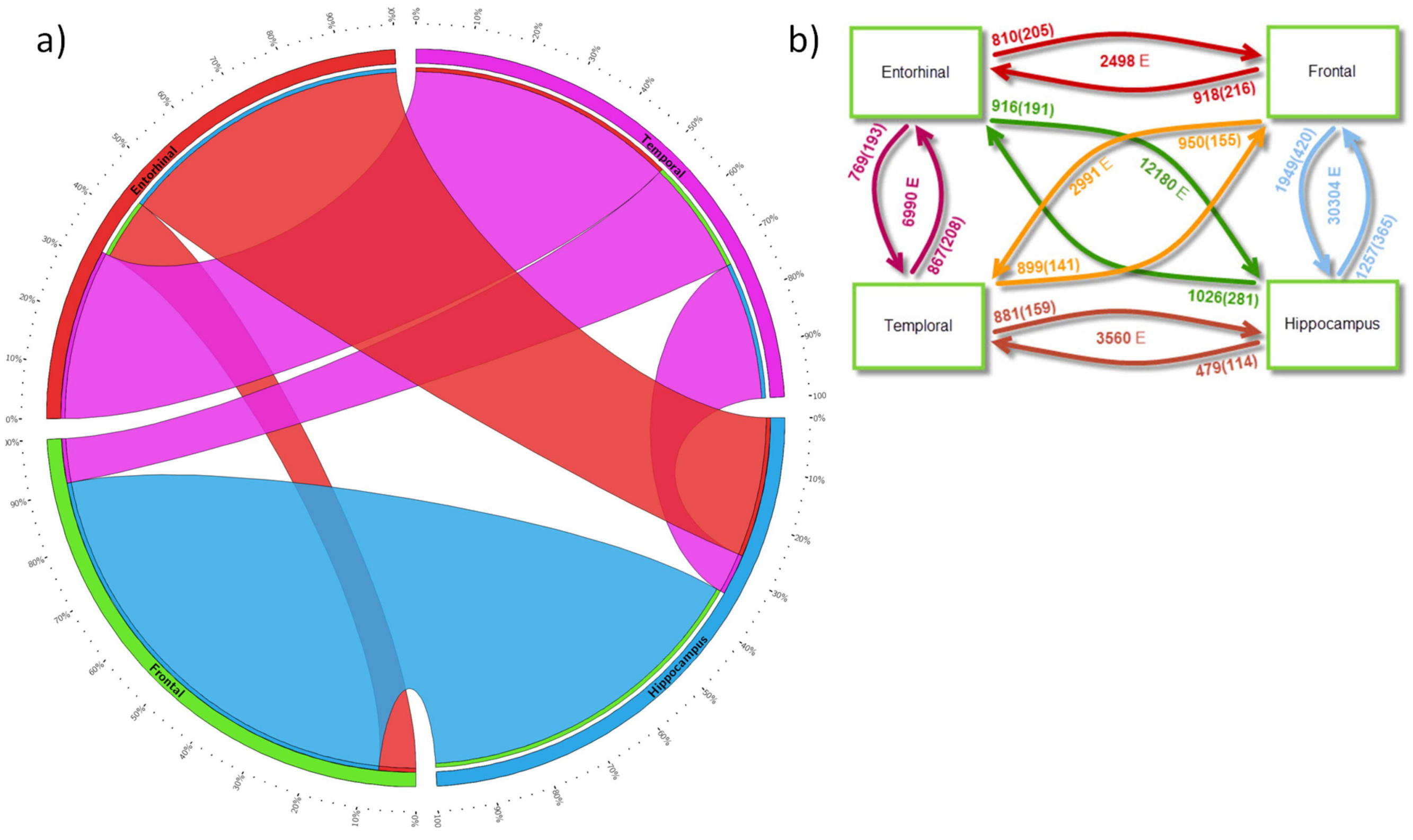



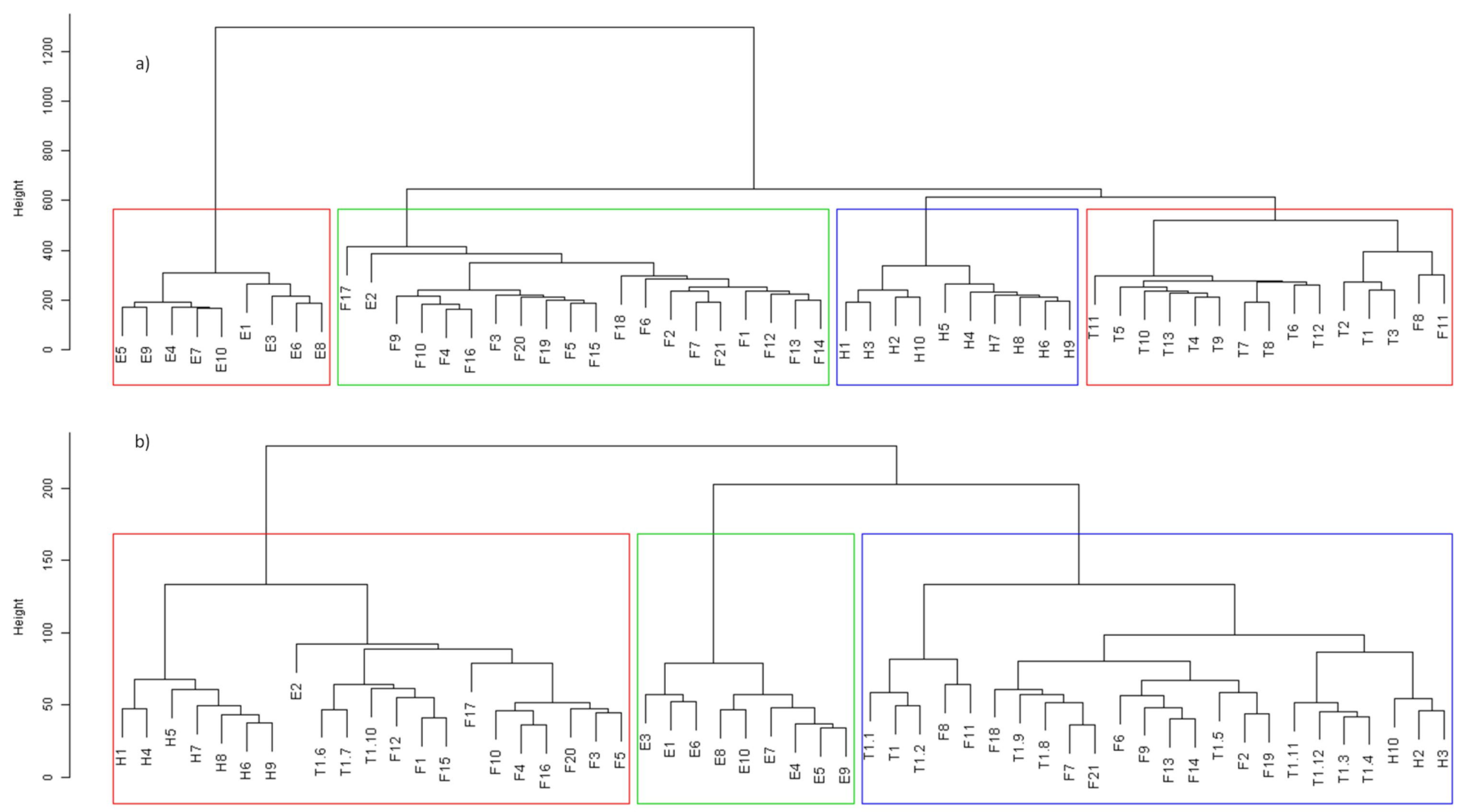


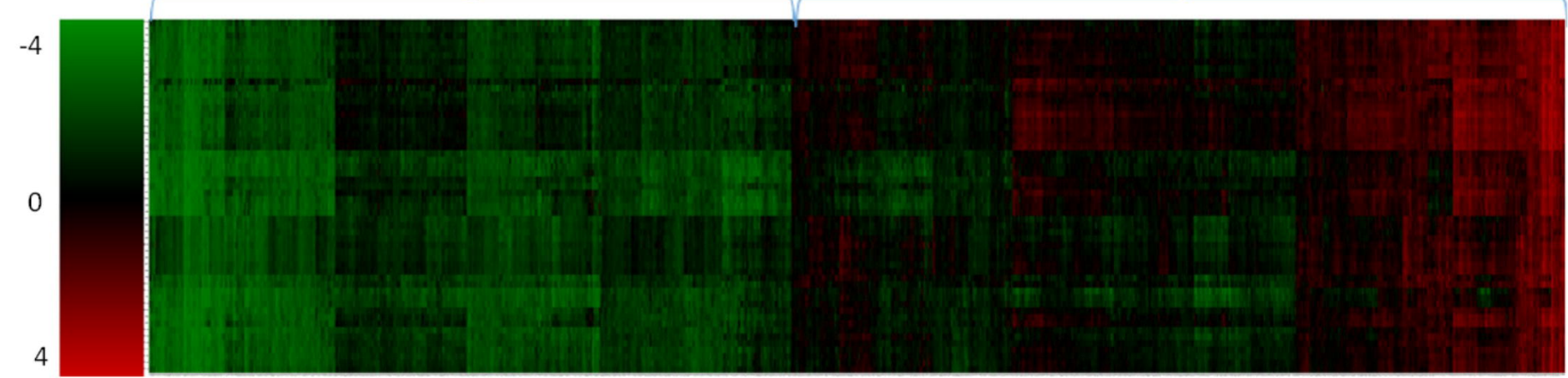









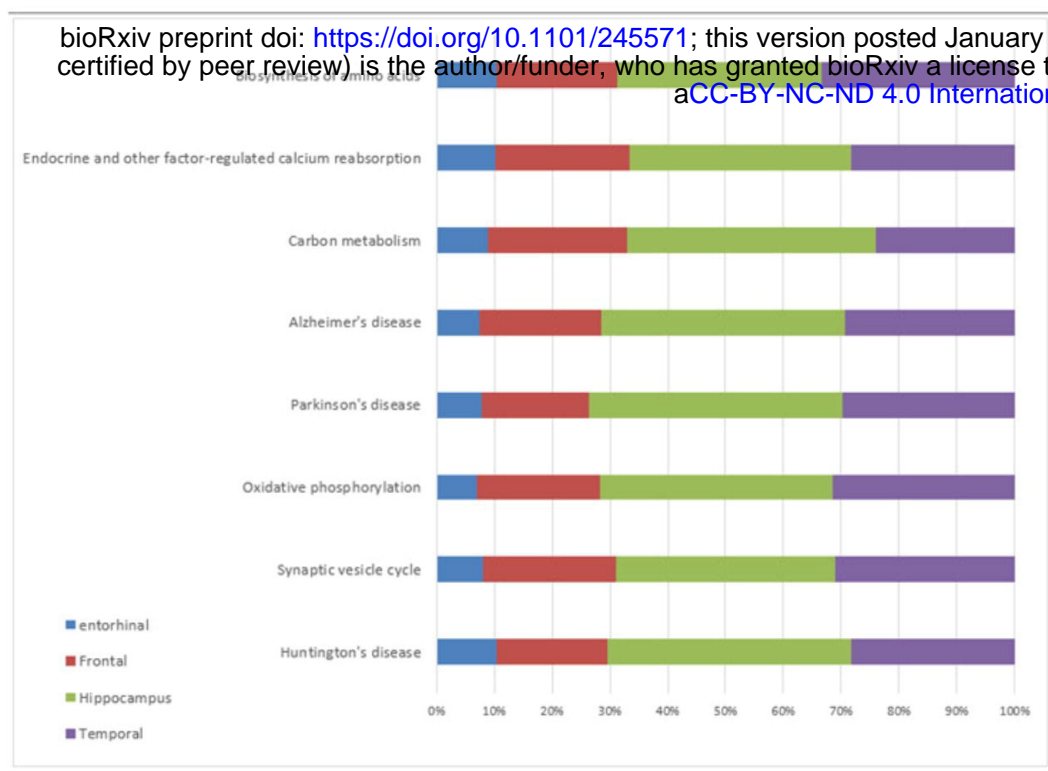
bioRxiv preprint doi: https://doi.org/10.1101/245571; this version posted January 9,2018 . The copyright holder for this preprint (which was not
certified by peer review) is the author/funder, who has granted bioRxiv a license to display the preprint in perpetuity. It is made available under certified by peer review) is the author/funder, who has granted bioRxiv a license to display the preprint in perpetuity. It is made available under aCC-BY-NC-ND 4.0 international license.

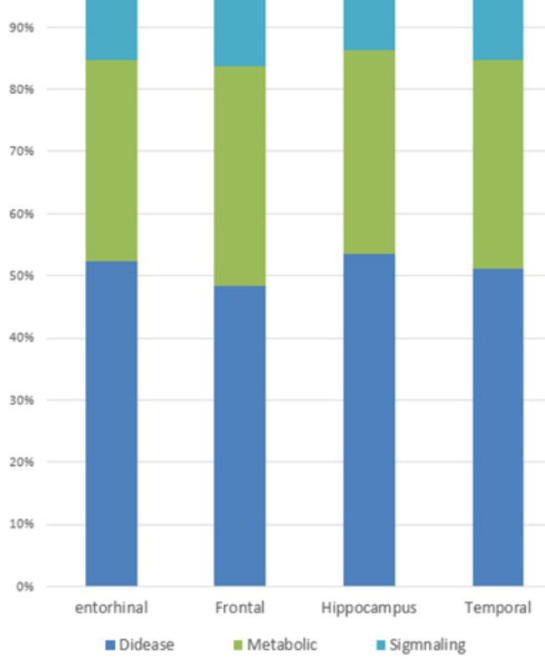


a)
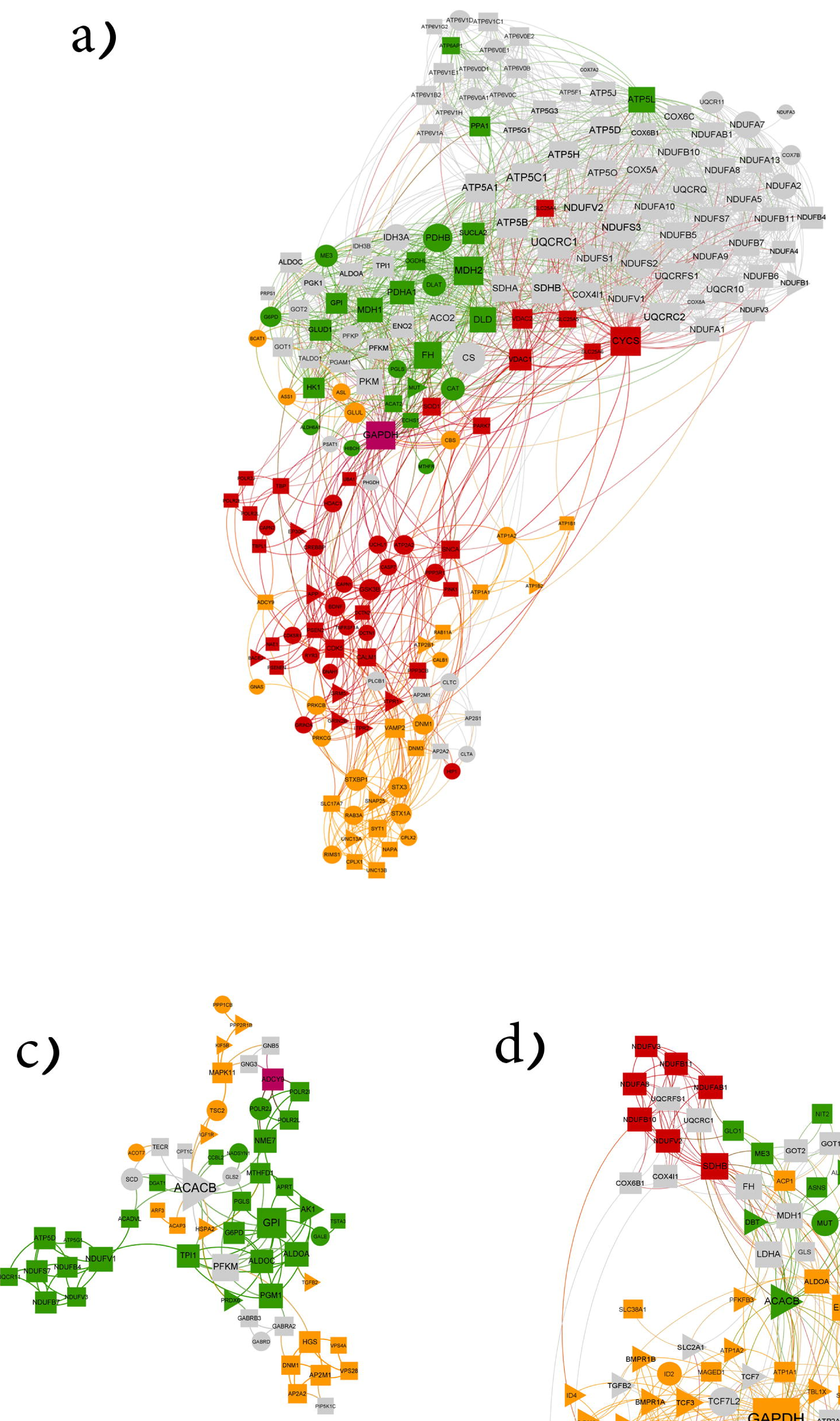

Metabolic pathways

Signailing pathways

Disease pathways

Common genes

between two pathways

Common genes

Degree

10

Down regulated genes

not changes in

expression genes

Up regulated genes

b)

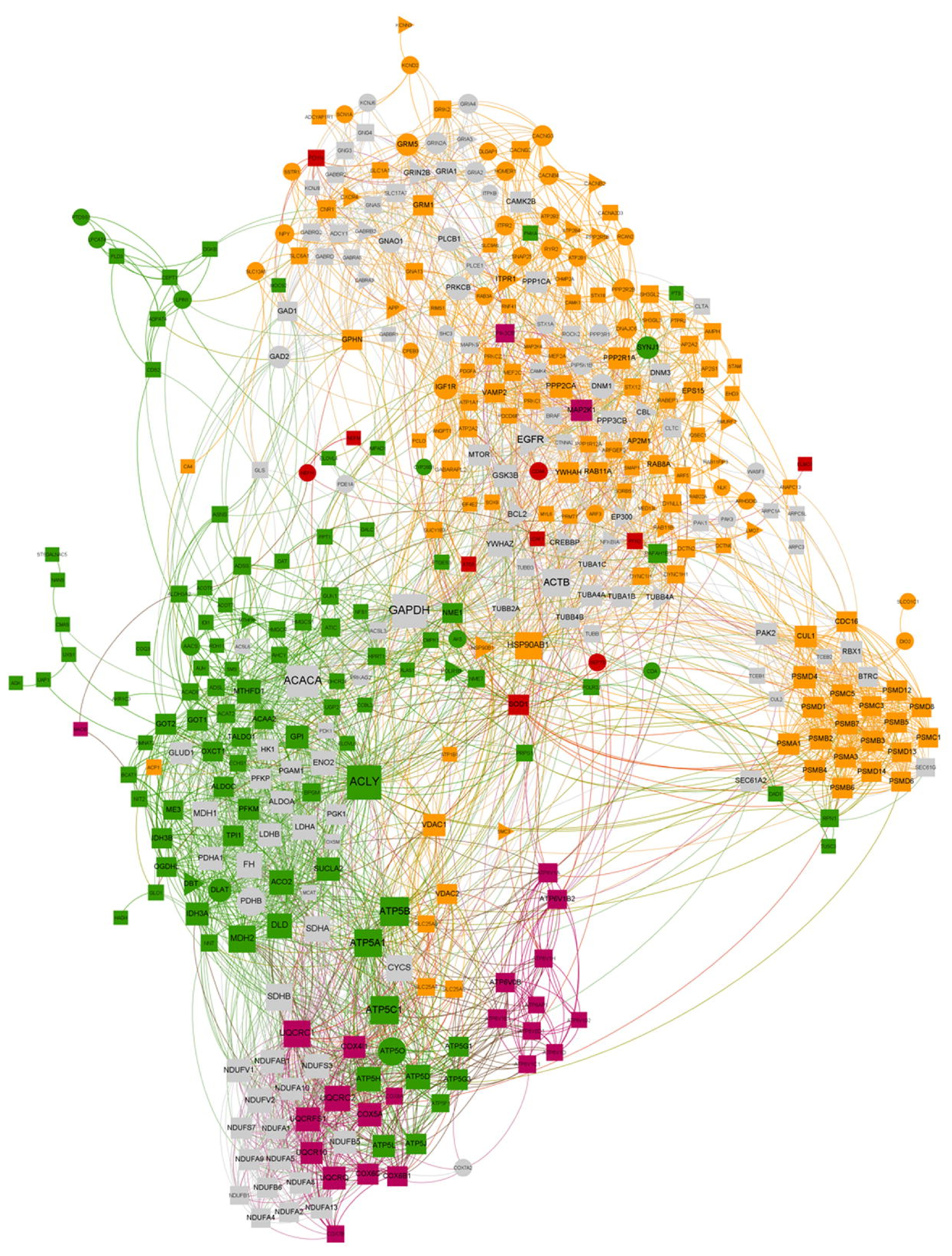

d)

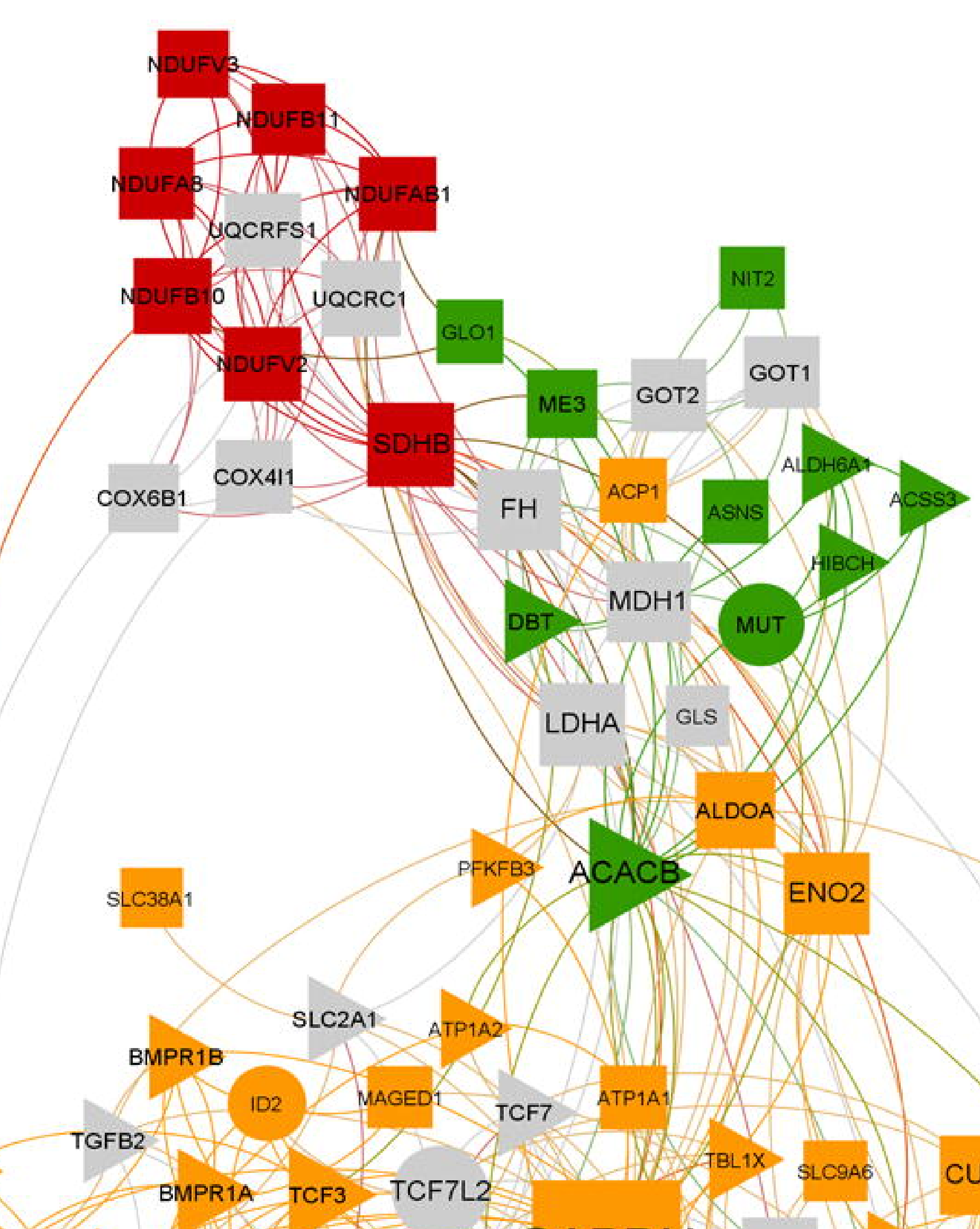

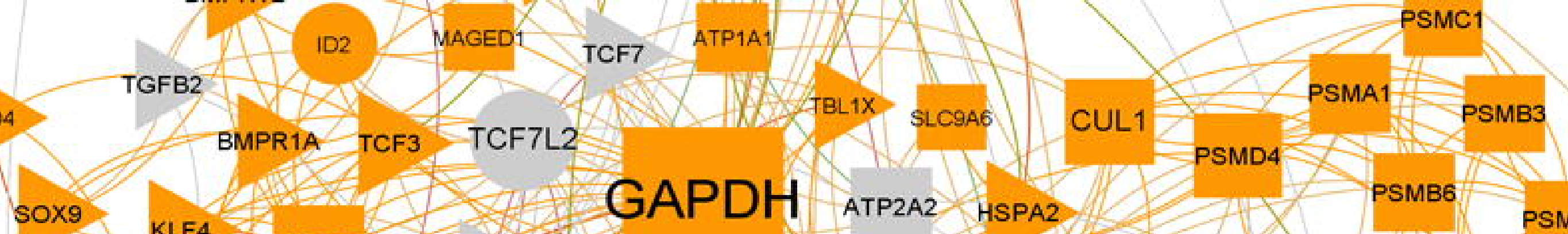

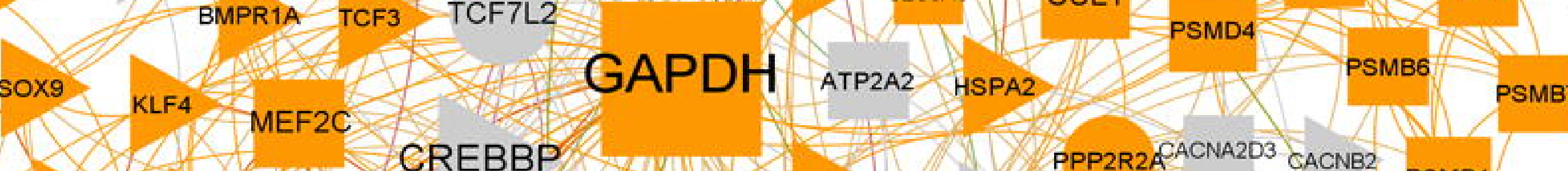

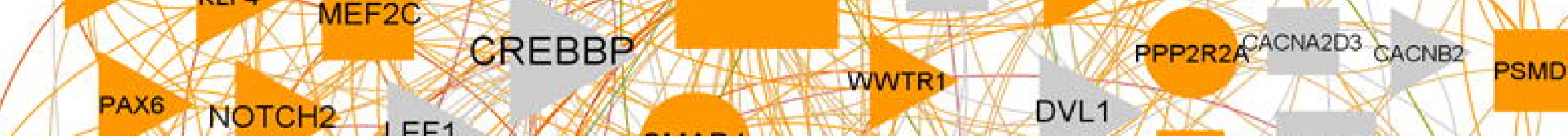

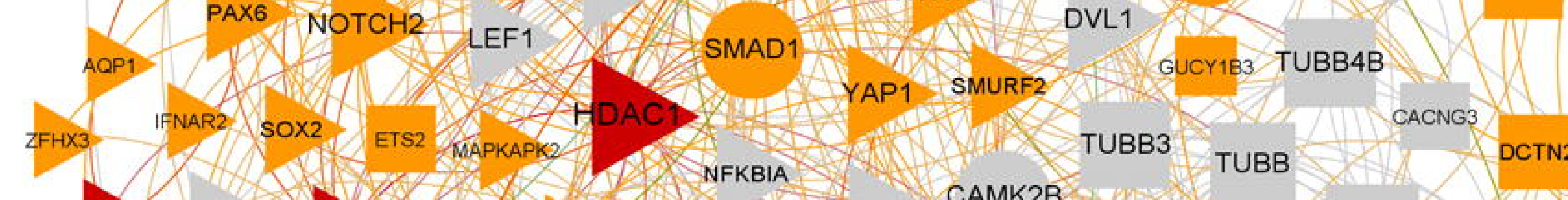

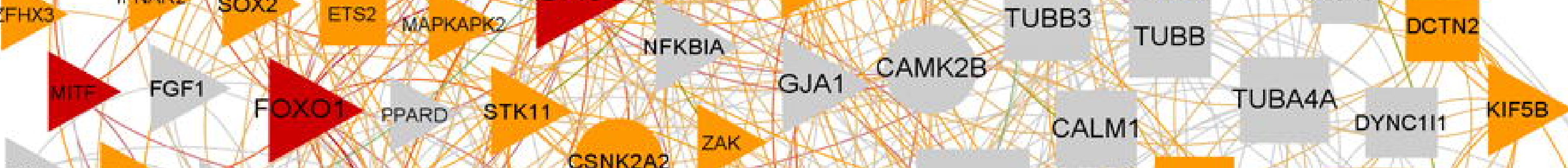

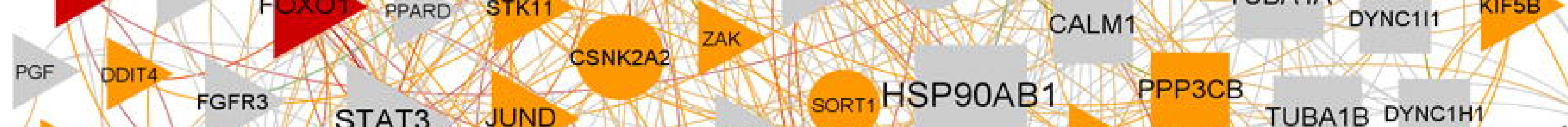

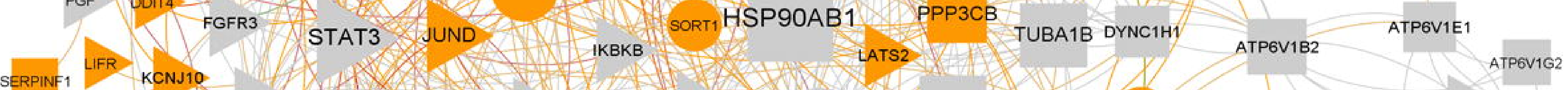

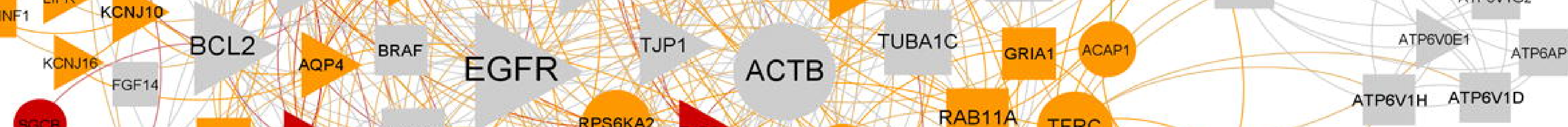

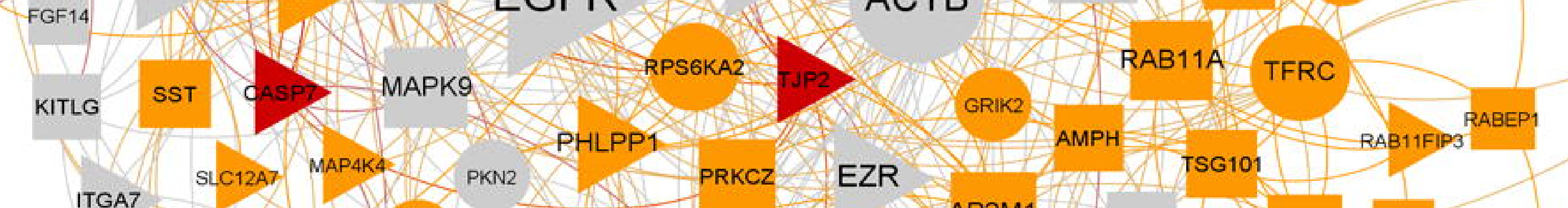

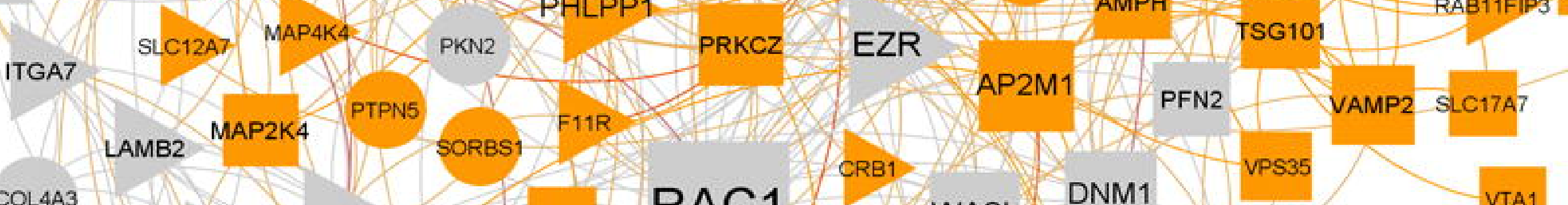

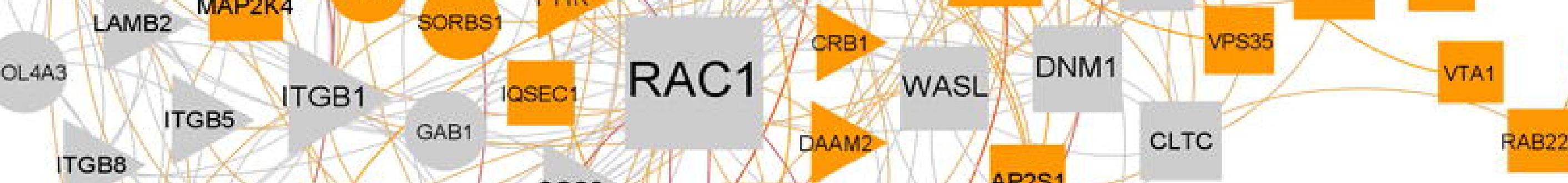

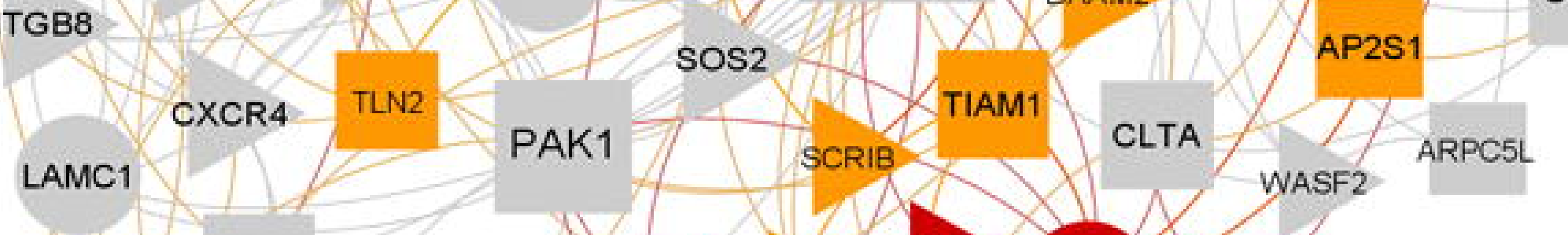

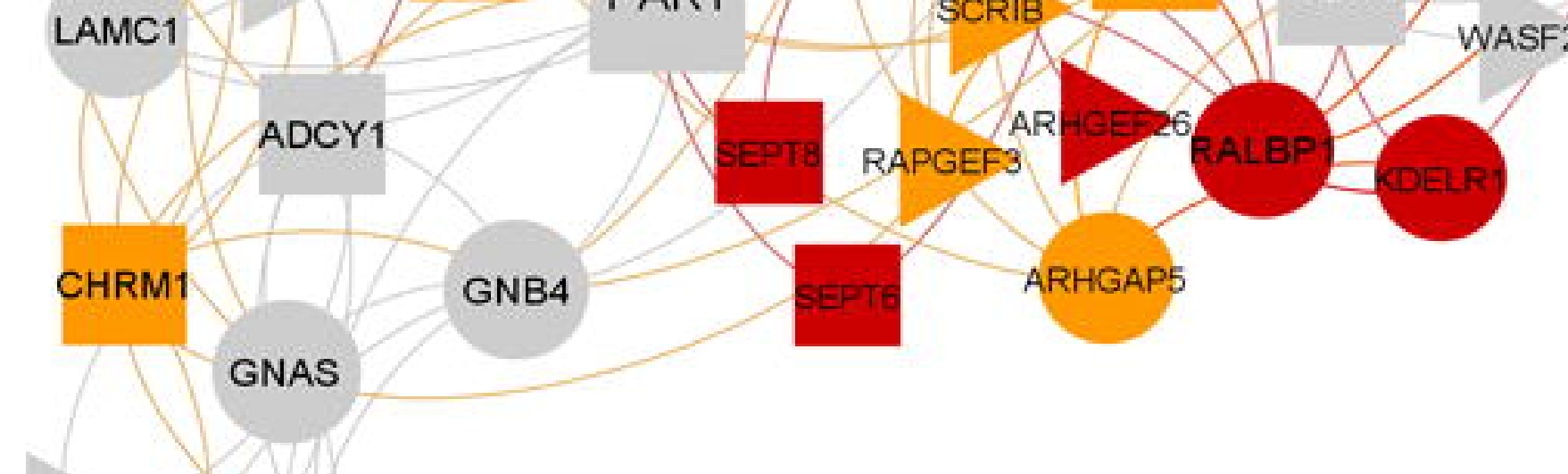

GDRB ${ }_{\text {GNO12 }}$ e)
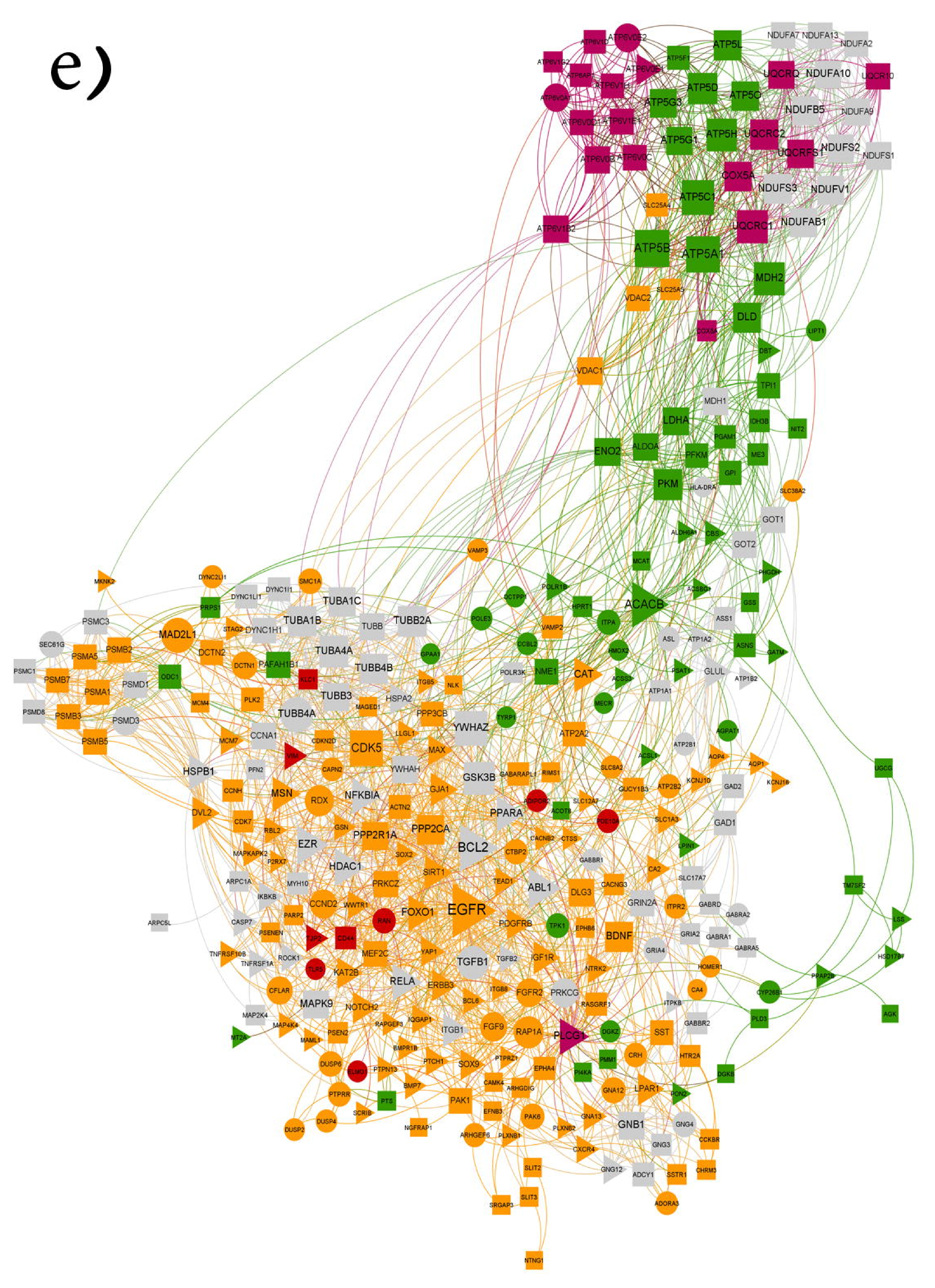


\begin{tabular}{|c|c|c|c|c|}
\hline Lobe & Series ID & Library & controls/cases & $\begin{array}{l}\text { controls/cases } \\
\text { after meta- } \\
\text { analysis }\end{array}$ \\
\hline \multirow{3}{*}{ Frontal } & GSE5281 & HG-U133_Plus_2 & $5 / 21$ & \multirow{3}{*}{$58 / 45$} \\
\hline & GSE48350 & HG-U133_Plus_2 & $45 / 19$ & \\
\hline & GSE12685 & HG-U133A & $8 / 5$ & \\
\hline \multirow{4}{*}{ Hippocampus } & GSE28146 & HG-U133_Plus_2 & $8 / 7$ & \multirow{4}{*}{$65 / 53$} \\
\hline & GSE5281 & HG-U133_Plus_2 & $5 / 21$ & \\
\hline & GSE48350 & HG-U133_Plus_2 & $42 / 19$ & \\
\hline & GSE1297 & HG-U133A & $10 / 6$ & \\
\hline \multirow{3}{*}{ Entorhinal } & GSE4757 & HG-U133_Plus_2 & $7 / 8$ & \multirow{3}{*}{$55 / 32$} \\
\hline & GSE5281 & HG-U133_Plus_2 & $11 / 10$ & \\
\hline & GSE48350 & HG-U133_Plus_2 & $37 / 14$ & \\
\hline \multirow{2}{*}{ Temporal } & GSE5281 & HG-U133_Plus_2 & $11 / 13$ & \multirow{2}{*}{$27 / 15$} \\
\hline & GSE21779 & HG-U133_Plus_2 & $16 / 2$ & \\
\hline
\end{tabular}




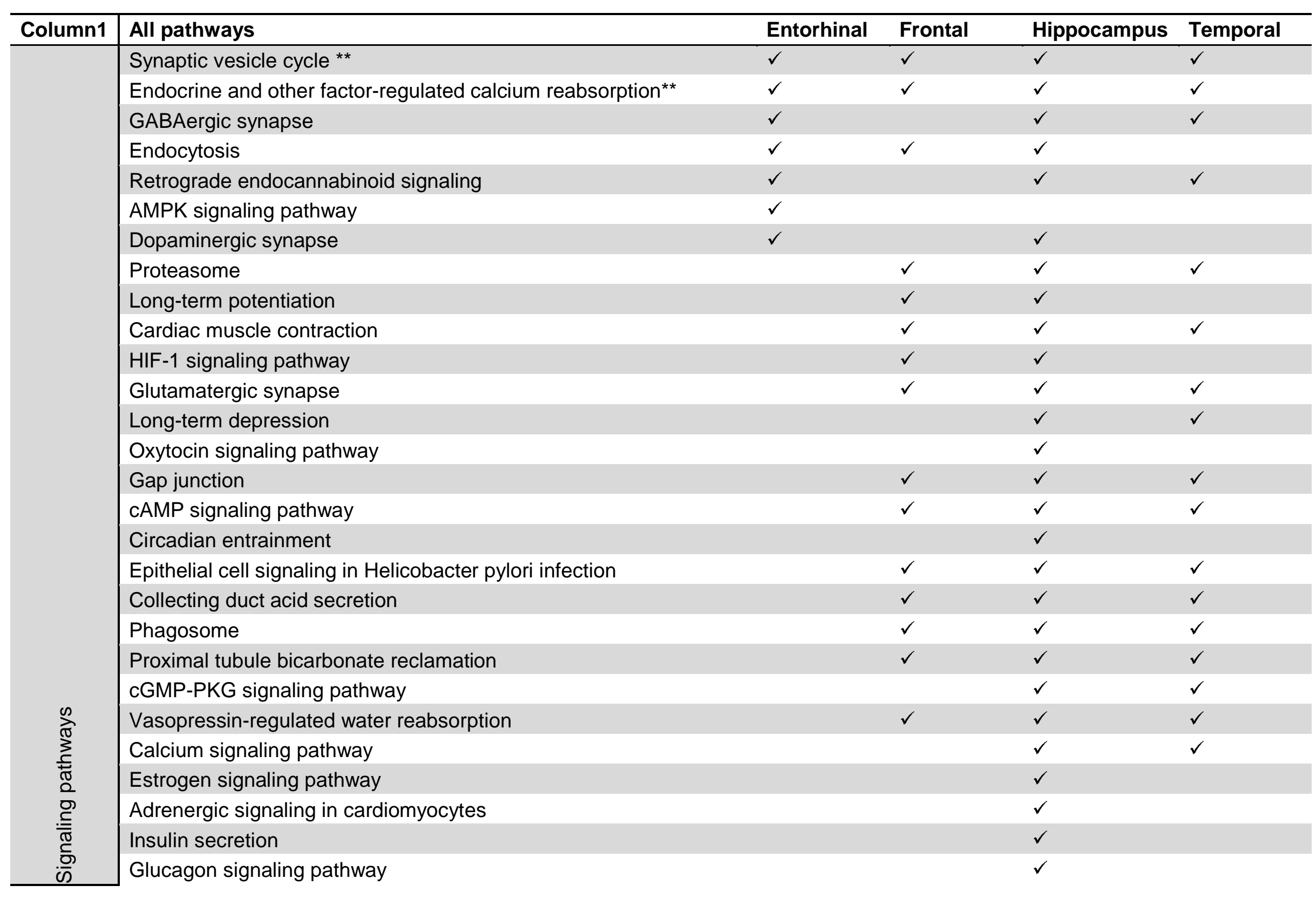




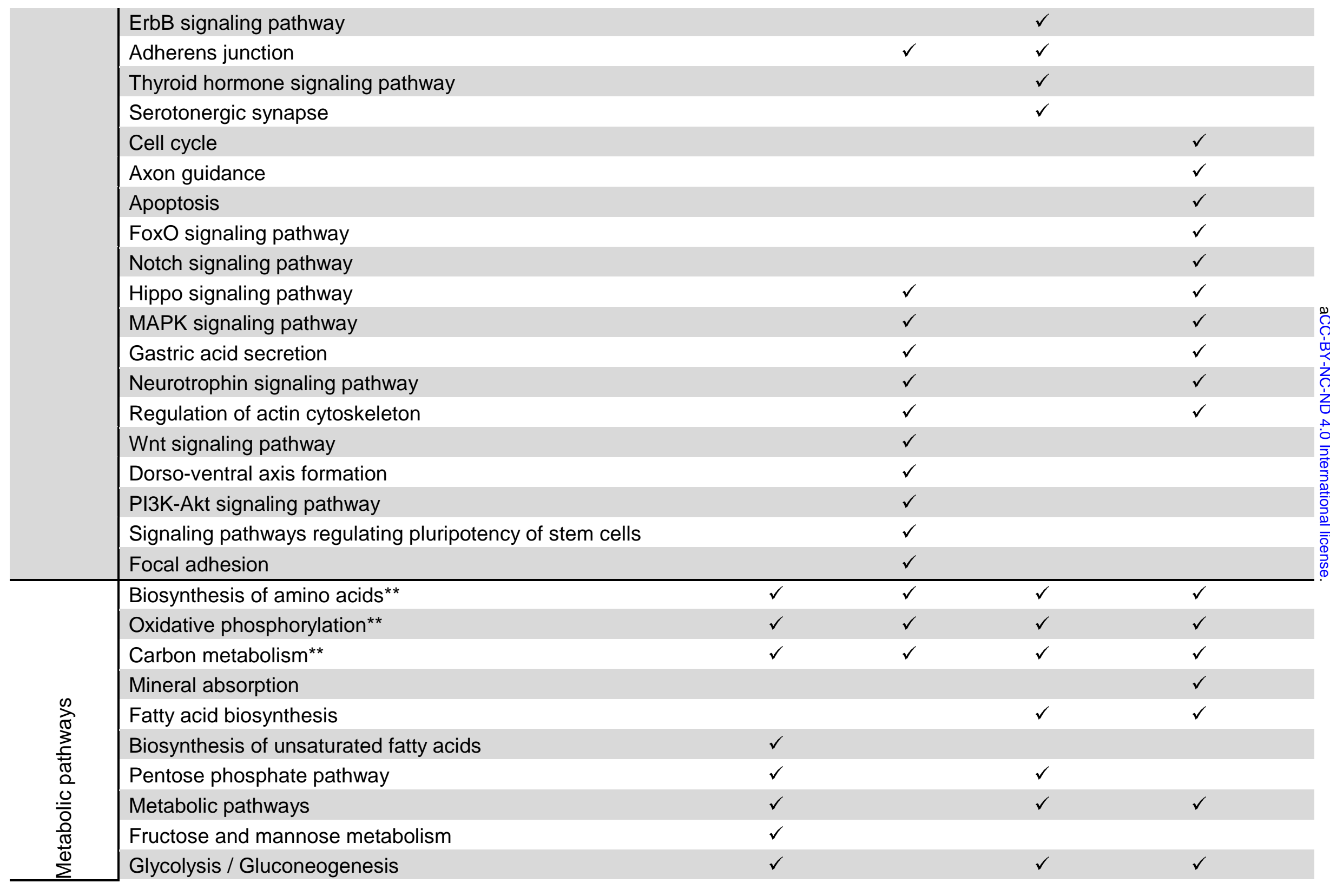




\begin{tabular}{|c|c|c|c|c|c|}
\hline & Purine metabolism & $\checkmark$ & & & \\
\hline & Fatty acid metabolism & $\checkmark$ & & $\checkmark$ & \\
\hline & Amino sugar and nucleotide sugar metabolism & $\checkmark$ & & & \\
\hline & Galactose metabolism & $\checkmark$ & & & \\
\hline & Arginine biosynthesis & & $\checkmark$ & & $\checkmark$ \\
\hline & Citrate cycle (TCA cycle) & & & $\checkmark$ & \\
\hline & Pyruvate metabolism & & $\checkmark$ & $\checkmark$ & $\checkmark$ \\
\hline & Alanine, aspartate and glutamate metabolism & & $\checkmark$ & $\checkmark$ & $\checkmark$ \\
\hline & Valine, leucine and isoleucine degradation & & & $\checkmark$ & \\
\hline & Central carbon metabolism in cancer & & & $\checkmark$ & \\
\hline & 2-Oxocarboxylic acid metabolism & & & $\checkmark$ & \\
\hline & Cysteine and methionine metabolism & & & $\checkmark$ & \\
\hline & Propanoate metabolism & & $\checkmark$ & $\checkmark$ & \\
\hline & Butanoate metabolism & & & $\checkmark$ & \\
\hline & Fatty acid elongation & & & $\checkmark$ & $\checkmark$ \\
\hline \multirow{14}{*}{ 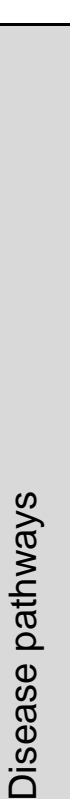 } & Huntington's disease $e^{\star \star}$ & $\checkmark$ & $\checkmark$ & $\checkmark$ & $\bar{\checkmark}$ \\
\hline & Parkinson's disease ${ }^{\star \star}$ & $\checkmark$ & $\checkmark$ & $\checkmark$ & $\checkmark$ \\
\hline & Alzheimer's disease ${ }^{\star *}$ & $\checkmark$ & $\checkmark$ & $\checkmark$ & $\checkmark$ \\
\hline & Morphine addiction & $\checkmark$ & & $\checkmark$ & $\checkmark$ \\
\hline & Non-alcoholic fatty liver disease (NAFLD) & & $\checkmark$ & $\checkmark$ & $\checkmark$ \\
\hline & Vibrio cholerae infection & & $\checkmark$ & $\checkmark$ & $\checkmark$ \\
\hline & Nicotine addiction & & & $\checkmark$ & $\checkmark$ \\
\hline & Amphetamine addiction & & & $\checkmark$ & \\
\hline & Pathogenic Escherichia coli infection & & $\checkmark$ & $\checkmark$ & $\checkmark$ \\
\hline & Amyotrophic lateral sclerosis (ALS) & & & $\checkmark$ & \\
\hline & Shigellosis & & $\checkmark$ & $\checkmark$ & $\checkmark$ \\
\hline & Bacterial invasion of epithelial cells & & $\checkmark$ & $\checkmark$ & \\
\hline & Renal cell carcinoma & & $\checkmark$ & $\checkmark$ & \\
\hline & Arrhythmogenic right ventricular cardiomyopathy (ARVC) & & $\checkmark$ & & \\
\hline
\end{tabular}




\begin{tabular}{|lcc} 
Dilated cardiomyopathy & $\checkmark$ \\
Pathways in cancer & $\checkmark$ \\
Prostate cancer & $\checkmark$ & $\checkmark$ \\
Hypertrophic cardiomyopathy (HCM) & $\checkmark$ & \\
Salmonella infection & $\checkmark$ & $\checkmark$ \\
Acute myeloid leukemia & $\checkmark$ & $\checkmark$ \\
Colorectal cancer & $\checkmark$ & $\checkmark$ \\
Melanogenesis & $\checkmark$ & \\
Pancreatic cancer & & \\
Rheumatoid arthritis & & \\
Epstein-Barr virus infection & & \\
\hline
\end{tabular}




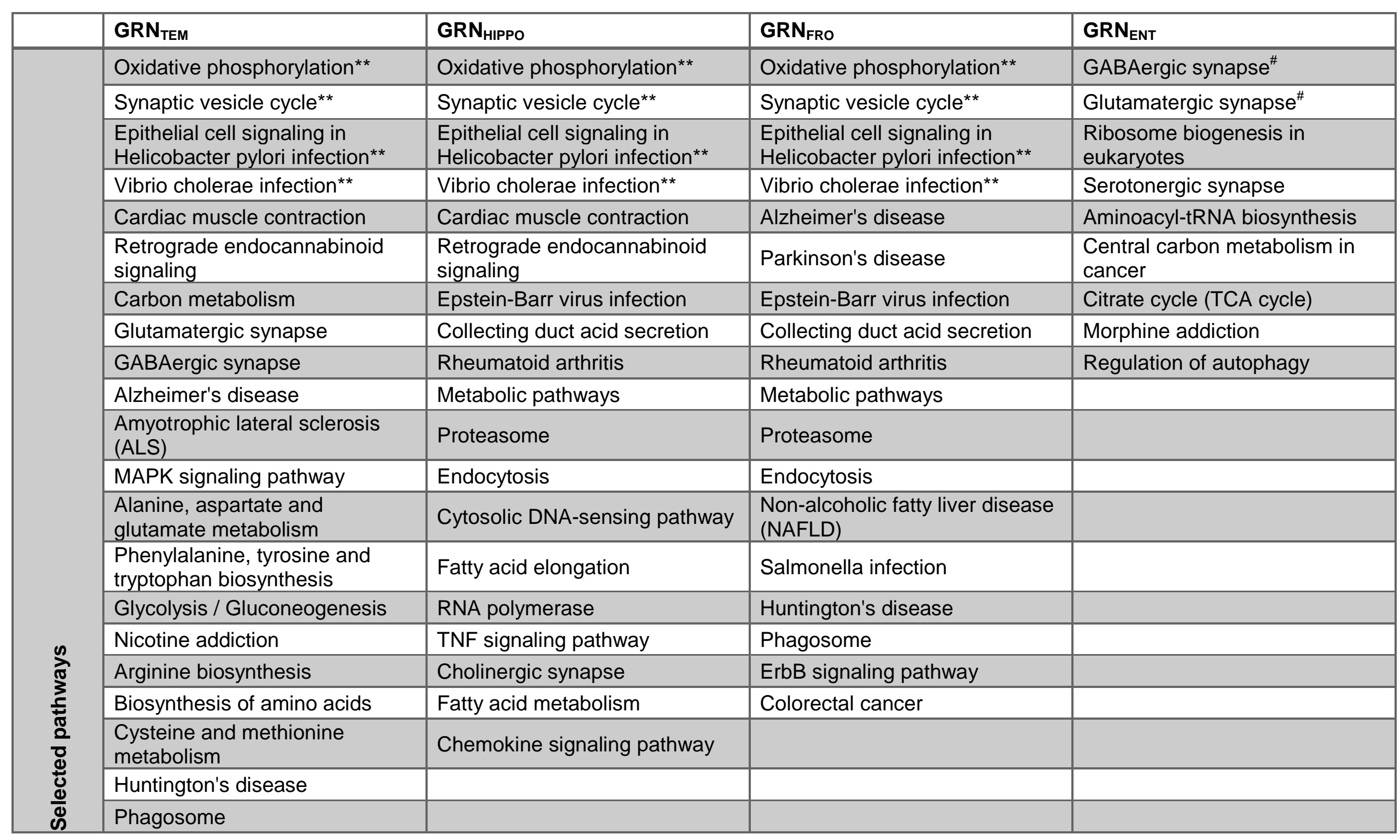




\begin{tabular}{|l|l|l|l|l|}
\hline Regions & $\begin{array}{l}\text { Up-regulated genes } \\
\text { NO }\end{array}$ & Validity percent & $\begin{array}{l}\text { Down-regulated } \\
\text { genes NO }\end{array}$ & Validity percent \\
\hline Hippocampus & 25 & 84 & 229 & 98 \\
\hline Temporal & 29 & 76 & 137 & 99 \\
\hline Frontal & 41 & 93 & 79 & 94 \\
\hline Entorhinal & 5 & 100 & 41 & 95 \\
\hline
\end{tabular}

